\title{
MODEL PENGINJILAN DALAM YOHANES 4:4-42 DAN IMPLEMENTASINYA PADA MASA KINI
}

\author{
Stefany John Risna Abrahamsz \\ sttjaffraymakassar@yahoo.co.id \\ Petronella Nelly Tuhumury \\ sttjaffraymakassar@yahoo.co.id
}

\begin{abstract}
ABSTRAK
Sesuai dengan permasalahan yang ada, maka tujuan penulisan karya ilmiah ini adalah: Pertama, untuk mengetahui model penginjilan dalam Yohanes 4:4-42 dapat diterapkan. Kedua, untuk mengetahui implementasi model penginjilan pada masa kini.

Adapun metode penulisan yang digunakan dalam penulisan karya ilmiah ini untuk mendapatkan data yang diperlukan adalah: Metode yang dipakai oleh penulis dalam penelitian ini adalah metode hermeneutik Alkitab, yaitu metode penelitian kepustakaan (library research) terhadap berbagai sumber data atau naskah-naskah yang mendukung serta memiliki korelasi dengan judul, di mana Alkitab merupakan sumber utama serta menggunakan metode eksigesis yang disusun secara deskriptif untuk mencapai sasaran dan tujuan penulisan.

Berdasarkan uraian penulis dalam penulisan karya ilmiah tentang model penginjilan dalam Yohanes 4:4-42 dan implementasinya pada masa kini, maka penulis dapat menarik kesimpulan sebagai berikut: Pertama, penginjilan adalah tugas utama bagi setiap gereja dan orang percaya secara pribadi yang telah menerima keselamatan dari Allah. Kedua, penginjilan adalah wujud kasih orang percaya kepada Allah dan kepada sesama manusia. Ketiga, penginjilan adalah pekerjaan yang mulia, sebab membawa setiap manusia mengenali akan dosanya lalu bertobat menerima Yesus sebagai juruselamat, dan percaya dengan sungguh bahwa di dalam Yesus ada keselamatan, pengharapan dan kepastian hidup yang kekal. Keempat, Penginjilan merupakan pelayanan yang memiliki kekuatan Kuasa Allah, dan hal ini hanya dapat dilakukan oleh Roh Kudus (Lukas 24:49). Kelima, Sebelum memulai pemberitaan Injil terlebih dahulu haruslah menerima kuasa Roh Kudus. Keenam, Penginjil harus mengalami perjumpaan dengan Kristus terlebih dahulu sebelum menjadi saksi bagi Kristus dan menjadi berkat bagi hidup sesama.
\end{abstract}

Kata kunci: Model Penginjilan, Yohanes 4:4-42, masa kini 


\section{PENDAHULUAN}

\section{Latar Belakang Masalah}

Penginjilan merupakan tanggungjawab setiap orang percaya untuk memberitakan karya keselamatan Allah melalui Kristus. J.I Packer berpendapat bahwa "Penginjilan adalah bagian dari rencana kekal Allah yang termanifestasi dalam penyataan Yesus Kristus dan karya-Nya kepada manusia yang berdosa sebagai satu-satunya harapan baik di dunia maupun dunia yang akan datang."

Demikian juga, setiap orang percaya yang telah menerima keselamatan dari Allah bertanggung jawab untuk menyampaikan berita keselamatan tersebut melalui pimpinan Allah dan Roh Kudus. J.I. Packer menjelaskan tentang penginjilan menurut Paulus, "Penginjilan adalah pergi dalam kasih, sebagai utusan Kristus di dalam dunia, untuk mengajarkan kebenaran Injil kepada orang berdosa, dengan tujuan untuk mempertobatkan dan menyelamatkan mereka".

Penginjilan atau pemberitaan Injil bukan saja harus dijalankan oleh gereja secara kolektif, melainkan juga harus dilakukan oleh setiap orang percaya secara pribadi masing-masing. Hati yang mengasihi jiwa-jiwa yang belum mendengar Injil dan yang belum mengenal Yesus Kristus, adalah unsur yang sangat penting dalam melaksanakan penginjilan. ${ }^{3}$

Stephen Tong menegaskan bahwa, barang siapa pernah mengalami kuasa Injil akan memperoleh keberanian yang besar untuk menginjili jiwa-jiwa yang memerlukan Injil. Segala konsep, segala hambatan, kebudayaan, segala batasan, agama, tidak akan menghentikan mereka dari keberanian menginjili. Kuasa Roh Kudus ada pada mereka, akan memenuhi mereka sehingga mereka berani menghadapi segala kesulitan di dalam penginjilan. ${ }^{4}$

Gereja harus bertanggungjawab untuk pergi memberitakan Injil sebab, keselamatan hanya diperoleh di dalam dan melalui Yesus Kristus dan bahwa hanya Dia jalan satu-satunya yang bisa menjamin untuk menuju hidup yang kekal. Di luar Dia tidak ada kesalamatan. Setiap orang percaya juga harus memiliki rasa tanggungjawab dalam memberitakan Injil dengan motif yang positif. Ada dua motif yang seharusnya mendorong kita untuk terus-menerus menginjil. Motif yang

\footnotetext{
IJ.I Packer, Evangelism And The Sovereignty Of God (Surabaya: Momentum, 2009), 27. ${ }^{2}$ Ibid. 40.

“"Strategi Misi Model Kontekstualisasi," Buletin Mitra. Oktober-Desember 2007,

${ }^{4}$ Stephen Tong, Teologi Penginjilan (Jakarta: LRII, 1988), 65-66.
} 3. 
pertama adalah kasih kepada Allah dan kerinduan untuk memuliakan Dia; Motif kedua adalah kasih kepada sesama manusia dan kepedulian akan keselamatan mereka.

D.W. Ellis berpendapat bahwa, seringkali orang percaya segan atau malas melaksanakan penginjilan, penyebabnya antara lain: Sikap tak acuh terhadap keadaan buruk sesama manusia, takut kepada sesama manusia, takut kepada orang yang mendatangkan jerat Amsal 29:25. Ketakutan kepada sesama manusia juga bermacam-macam antara lain; pertama takut ditertawakan, dibenci, dianiaya, dianggap aneh. Kedua takut kehilangan kedudukan dalam masyarakat. Ketiga malu karena belum mengerti atau menguasai asas kepercayaan, Kristen. Keempat malu karena kehidupan sebagai Kristen belum begitu baik. ${ }^{5}$ Ada juga sebagaian orang percaya yang memiliki kerinduan untuk memberitakan Injil tetapi mereka tidak tahu bagaimana melakukannya atau metodemetode apa yang akan mereka gunakan supaya dapat memberitakan Injil dengan baik. Oleh sebab berbagai hal tersebut, mendorong orang percaya memilih untuk tetap berada dalam zona nyaman dengan malaksanakan kegiatan-kegiatan pelayanan yang hanya berfokus dalam gereja, dibandingkan pergi menginjil.

Pelaksanaan penginjilan akan mengalami banyak tantangan, baik dari dalam diri sendiri maupun tantangan dari luar. Seperti, penolakan dan penganiayaan yang dapat menstagnasikan amanat Agung yang telah diperintahkan Allah bagi kita setiap orang percaya. Hal-hal inilah yang membuat Injil tidak bisa diberitakan kepada mereka yang belum pernah mendengarkan Injil. Seringkali gereja akan mengalami semangat dan bergelora di dalam roh, tetapi daging lemah, demikianlah yang dialami gereja terkadang mengalami gelora untuk pergi memberitakan Injil, tetapi setelah beberapa waktu kembali melemah bahkan akhirnya putus asa dan meninggalkan tugas pekabaran Injil. ${ }^{6}$

Untuk melakukan penginjilan tentunya ada metode-metode yang akan digunakan untuk efektifnya suatu penginjilan. Makmur Halim dalam bukunya yang berjudul Model-model Penginjilan Yesus mengatakan bahwa: "Dalam dunia penginjilan kita mengenal banyak teori atau metode penginjilan yang diterapkan dalam pelayanan. Teori-teori ini melahirkan banyak metode-metode penginjilan dan praktik-praktik penginjilan yang sangat beragam."7

${ }^{5}$ D.W. Ellis, Metode Penginjilan (Jakarta: Yayasan Komunikasi Bina Kasih/OMF, 2005), 8.

${ }^{6}$ D.W. Ellis, Metode Penginjilan, 8.

${ }^{7}$ Makmur Halim, Model-model Penginjilan Yesus Suatu Penerapan Masa Kini, (Malang: Gandum Mas, 2003), 17. 
Berdasarkan latar belakang di atas, maka penulis bermaksud menulis sebuah skirpsi dengan judul: "Model Penginjilan Dalam Yohanes 4:4-42 Dan Implementasinya Pada Masa Kini”.

\section{Masalah Pokok}

Berdasarkan masalah di atas, yang menjadi pokok masalah dalam penulisan penelitian ini adalah : Pertama, bagaimana model penginjilan dalam Yohanes 4:4-42? Kedua, Bagaimana implementasi model penginjilan dalam Yohanes 4:4-42 pada masa kini?

\section{Tujuan Penulisan}

Adapun tujuan penulisan yang hendak dicapai sehubungan dengan penelitian ini, adalah sebagai berikut: Pertama, untuk mengetahui model penginjilan dalam Yohanes 4:4-42 dapat diterapkan. Kedua, untuk mengetahui implementasi model penginjilan pada masa kini.

\section{Manfaat Penulisan}

Adapun manfaat dalam penulisan penelitian ini tentang model penginjilan berdasarkan Injil Yohanes 4:1-42 adalah: Pertama, agar penelitian ini dapat menjadi bahan bacaan yang dapat menambah wawasan bagi para pembaca. Kedua, agar dapat menjadi acuan serta dasar Alkitabiah dalam pengajaran mengenai model penginjilan.

\section{Metodologi Penulisan}

Metode yang dipakai oleh penulis dalam penelitian ini adalah metode hermeneutik Alkitab, yaitu metode penelitian kepustakaan (library research) terhadap berbagai sumber data atau naskah-naskah yang mendukung serta memiliki korelasi dengan judul.

\section{Batasan Penulisan}

Penggunaan pembahasan dalam penelitian ini terbatas hanya pada Injil Yohanes 4:4-42, yang membahas secara khusus tentang model penginjilan. Bilamana terdapat kutipan ayat-ayat dari Alkitab dan bukubuku yang ditulis oleh para pakar teologi sehubungan dengan model penginjilan, itu hanya merupakan referensi perbandingan. 


\section{EKSEGESIS INJIL YOHANES 4:4-42}

\section{Analisa Konteks}

\section{Sebelum Teks 3:22-4:3}

Sebelum Yesus kembali ke Galilea dan melintasi Samaria, Yesus sedang berada di Yudea bersama murid-murid-Nya. Murid-murid Yesus membabtis orang-orang yang ada di tempat mereka dan di saat yang bersamaan Yohanes pun membabtis di Ainon, dekat Salim. Dalam Yoh. 3:22-26 adalah bagian yang sederhana, namun jelas menjadi pentas bagi perkataan Yohanes Pembabtis. Baik ia maupun Yesus (atau muridmurid Yesus, tergantung bagaimana memahami pasal 4:2) sama-sama membabtis, namun Yesus muncul dengan meminta lebih banyak perhatian. Hal ini wajar saja, sebab membuat murid-murid Yohanes Pembabtis khawatir. Bahkan mereka mengutarakan persoalan ini kepada guru mereka dengan ungkapan yang dapat dipahami : "Semua Orang pergi kepada-Nya dan bukan kepada kita!"

Dalam ayat 27-30 berisi kesaksian Yohanes Pembaptis. Orang dapat memberikan sesuatu kepada orang lain, apabila apa yang mulamula diberikan Allah kepadanya. Akibatnya, Yohanes Pembabtis tidak dapat bertindak lebih banyak daripada memberi kesaksian tentang Dia yang diberikan Allah kepadanya. Yohanes Pembabtis membandingkan dirinya sendiri dengan pendamping mempelai pada sebuah pernikahan, yang tujuannya bukan untuk menjadi pusat perhatian, namun hanyalah berdiri di samping dan menghormati mempelai. Akibatnya, Yesus harus semakin bertambah, sementara peran Yohanes harus berkurang. ${ }^{9}$

Dalam ayat 31-36 ada perkataan-perkataan yang diucapkan oleh Yohanes Pembabtis dan ada juga perkataan penulis Injil yang dimunculkan melalui kesaksian dari mulut Yohanes Pembabtis. Perkataan-perkataan itu mulai dengan sebuah tema penting dalam Injil Yohanes yaitu Asal-usul Yesus. Karena Yesus berasal dari Sorga, Dia lebih besar daripada semua manusia (dan pernyataan itu sendiri menjadi penghubung satu-satunya yang sangat jelas melalui kata-kata Yohanes Pembabtis di dalam pasal 3:31-36). Sekalipun Yesus tidak diterima, perkataan-Nya adalah perkataan Allah karena Allah telah memenuhiNya dengan Roh Kudus. Bapa mengasihi Anak dan inilah alasannya mengapa Yesus memiliki Kuasa Allah. Barangsiapa percaya kepada Yesus, ia memiliki hidup yang Kekal, namun siapa yang tidak taat, tidak mendapatkan kehidupan, melainkan hanya murka Allah. Sebuah pernyataan tegas yang ditulis di pasal 3:36 berfungsi sebagai selingan singkat. Perhatikan bahwa lawan dari percaya (ay.36) adalah

\footnotetext{
${ }^{8}$ Robert Kysar, Injil Yohanes Sebagai Cerita (Jakarta: BPK Gunung Mulia, 1995), 18. ${ }^{9}$ Ibid, 18-19.
} 
ketidaktaatan. Akibatnya, Ketaatan dalam pandangan Yohanes merupakan keinginan untuk menerima dan meyakini, atau dengan kata lain untuk mempercayai, Yesus. Ketaatan dan ketidaktaatan bukanlah persoalan tingkah laku moral melainkan keyakinan pribadi. ${ }^{10}$

\section{Sesudah Teks 4:43-54}

Setelah dua hari berada di Samaria Yesus pun berangkat ke Galilea tepatnya di Kana. Di kota ini, Yesus membuat mujizat, air berubah menjadi anggur manis.

Pegawai istana itu percaya kepada ucapan Yesus dan kembali ke rumahnya. Tepat seperti apa yang dinjanjikan Yesus kepadanya, terjadi mujizat anaknya sembuh, ia dan seluruh keluarganya percaya kepada Yesus. Kejadian ini merupakan tanda kedua yang Yesus lakukan di Galilea setelah yang pertama membuat air berubah menjadi anggur yang manis.

\section{MODEL PENGINJILAN DALAM YOHANES 4:4-42}

\section{Yesus Ke Daerah Samaria 4:4-6}

\section{Ia harus melintasi daerah Samaria}

Ayat 4, "Ia harus melintasi daerah Samaria." Kata "harus" berasal dari bahasa Yunani :Edei dari kata dei ${ }^{11}$ yang berarti mengharuskan, perlu, seharusnya. ${ }^{12}$ Bentuk kata kerja yang digunakan imperfek ${ }^{13}$ indikatif aktif orang ketiga tunggal. Penggunaan kata "harus" di sini menjelaskan bahwa pada waktu itu Dia (Yesus) harus melintasi daerah Samaria.

Kata "harus" dalam ayat ini lebih menyiratkan keharusan logis daripada kewajiban pribadi. Kata ini menyarankan bahwa alasan-Nya bukanlah keharusan geografis atau tekanan sosial, tetapi dorongan dasar dari kehendak Ilahi yang mencari domba Samaria yang hilang. ${ }^{14}$

Yesus "harus melintasi daerah Samaria". Ini berarti Ia harus melawan prasangka orang Yahudi dan orang Samaria. "Sebab orang Yahudi tidak bergaul dengan orang Samaria", tetapi "Orang Yahudi itu" (Yesus) melintasi daerah Samaria. Jalan lurus dari Yudea ke Galilea melintasi

\footnotetext{
${ }^{10} \mathrm{Ibid}, 19$.

Il "Edei" verb indicative imperfect active 3rd person singular from dei (BGM Morphology, Word Analysis s.v. "Edei” In Bible Work Version 7).

${ }^{12}$ Hasan Susanto, Perjanjian Baru Interlinear Yunani-Indonesia dan Konkordansi Perjanjian Baru (PBIK) Jilid II (Jakarta: LAI, 2003), 184.

${ }^{13}$ Kala imperfek menggambarkan tindakan kontinu yang biasanya terjadi di waktu lampau. Oleh William D. Mounce, Basics Of Biblical Greek (Malang: Literatur Saat, 2011), 154.

${ }^{14}$ Merril C. Tenney, Injil Iman (Malang: Gandum Mas, 1996), 89.
} 
daerah Samaria. Tetapi orang Yahudi merasa diri mereka lebih baik, mereka tidak mau melalui Samaria. Mereka biasanya menyeberang Sungai Yordan lalu masuk Galilea, mengelilingi Samaria. Yesus pernah mengalami prasangka itu ketika Ia sedang dalam perjalanan dari Galilea ke Yerusalem (lihat Luk 9:5l-56). Yesus hendak menghilangkan prasangka itu. Lagipula, Ia yakin bahwa kehendak Bapa-Nya adalah agar Ia mencari domba-domba (Samaria) yang hilang. ${ }^{15}$

\section{Sampailah di kota Sikhar}

Ayat 5, "Maka sampailah Ia ke sebuah kota di Samaria, yang bernama Sikhar dekat tanah yang diberikan Yakub dahulu kepada anaknya, Yusuf."

Kata "sampailah" dalam bahasa Yunani erkhetai dari kata erkhomai ${ }^{16}$ yang berarti datang, tiba, sampai. ${ }^{17}$ Bentuk kata kerja yang digunakan present indikatif middle orang ketiga tunggal. Kata "sampailah" mengindikasikan proses yang terus menerus berlangsung dalam perjalanan-Nya (melintasi Samaria).

Yesus tiba di salah satu kota yang bernama Sikhar. Kota ini berdiri pada persimpangan jalan, satu cabang jalan menuju ke Kapernaum dan cabang lainnya menuju ke Nazaret. Sumur Yakub berjarak satu setengah mil dari kota itu. ${ }^{18}$

Daerah ini penuh dengan ingatan terhadap sejarah masa lampau yang terjadi di situ. Di situ ada sebidang tanah yang telah dibeli oleh Yakub pada zaman dahulu (Kej 33:8-19). Ketika akan meninggal Yakub telah mewariskan tanah itu kepada Yusuf (Kej 48:22). Dan ketika Yusuf meninggal di Mesir maka jenazahnya dibawa kembali ke Palestina dan dikuburkan di sebidang tanah tersebut. (Yos 24:32). Jadi di tempat itu terdapat banyak peristiwa yang selalu diingat oleh orang Yahudi. ${ }^{19}$

Sekalipun banyak peristiwa penting tentang daerah itu bagi orang Yahudi, tetapi Yesus terus berjalan dan akhirnya Ia menghentikan perjalanannya ketika sampai di Sumur Yakub.

\section{Duduk di pinggir sumur}

Ayat 6, "Di situ terdapat sumur Yakub. Yesus sangat letih oleh perjalanan, karena itu Ia duduk di pinggir sumur itu. Hari kira-kira pukul dua belas." Dalam ayat 6 dikatakan "disitu terdapat sumur Yakub". Istilah sumur berasal

\footnotetext{
${ }^{15}$ J. Wesley Brill, Tafsiran Injil Yohanes (Bandung: Kalam Hidup, 1976), 49.

16 " erkhetai" verb indicative present middle 3rd person singular from e;rcomai (BGM Morphology, Word Analysis s.v. “erkhetai” In Bible Work Version 7).

${ }^{17}$ Hasan Susanto, Perjanjian Baru Interlinear Yunani-Indonesia dan Konkordansi Perjanjian Baru (PBIK) Jilid II (Jakarta: LAI, 2003), 316.

${ }^{18}$ Merril C. Tenney, Injil Iman (Malang: Gandum Mas, 1996), 89.

${ }^{19}$ Ibid,
} 
dari bahasa Yunani pege, berarti "mata air yang mengalir", bukan sumur. Istilah yang dipakai dalam ayat 11 dan 12 mengenai sumber air ini, yaitu phrear, berarti sumur. Ternyata sumber air ini merupakan sumur dan mata air, karena di dasar sumur ada sebuah mata air yang kuat, dan dapat diandalkan, dari zaman Yakub sampai masa kini Dalam Kej 16:7 dan 14, dan juga dalam Kej 24:11, 13, dan 16 istilah "mata air dan istilah sumur dipakai tentang sumber air yang sama. ${ }^{20}$

\section{Percakapan Yesus dengan perempuan Samaria 7-15}

Air Jasmani Ay. 7, 12.

"Maka datanglah seorang perempuan Samaria hendak menimba air. Kata Yesus kepadanya : Berilah Aku minum." Kata "berilah" dalam bahasa Yunani dos dari kata didomi ${ }^{21}$ yang berarti memberikan. ${ }^{22}$ Bentuk kata kerja yang digunakan aoris imperative aktif orang kedua tunggal. Kata "berilah" menjelaskan bahwa pada waktu itu Yesus meminta air kepada perempuan Samaria.

Ketika tengah hari waktu panas terik, datanglah seorang perempuan Samaria hendak menimba air. Biasanya perempuanperempuan datang pada waktu pagi dan sore. Mungkin perempuan itu adalah perempuan yang tidak baik dan tidak disukai oleh perempuanperempuan lain, karena itu ia datang ke sumur pada waktu tidak ada orang lain. Kebanyakan orang tidak mau berbicara dengan perempuan seperti itu, tetapi Yesus mau berbicara kepada perempuan itu, karena Ia tahu kebutuhan jiwa perempuan itu. ${ }^{23}$

Tuhan Yesus sungguh haus, Dia tidak pura-pura haus supaya Dia dapat berbicara dengan perempuan Samaria itu. ${ }^{24}$ Yesus meminta minum air, di sini Air menjadi sebuah benda yang betul-betul nyata. ${ }^{25}$ Kata minum dalam ayat 7 berasal dari bahasa Yunani pinô yang berarti 'minum; menghisap'. Yesus minta air kepada perempuan Samaria itu karena Ia haus akibat perjalanan panjang yang baru saja di tempuh-Nya. Yesus ingin menghilangkan dahaga yang dirasakan-Nya oleh sebab itu Ia meminta air kepada perempuan itu.

\footnotetext{
20 Deve Hagelberg, Tafsiran Injil Yohanes Pasal 1-5 Dari Bahasa Yunani (Yogyakarta:Yayasan Andi, 1990), 157.

21 "dos" verb imperative aorist active 2 nd person singular from di,dwmi (BGM Morphology, Word Analysis s.v. “dos” In Bible Work Version 7).

${ }^{22}$ Hasan Susanto, Perjanjian Baru Interlinear Yunani-Indonesia dan Konkordansi Perjanjian Baru (PBIK) Jilid II (Jakarta: LAI, 2003), 206.

${ }^{23}$ J. Wesley Brill, Tafsiran Injil Yohanes (Bandung: Kalam Hidup, 1976), 50.

${ }^{24}$ Deve Hagelberg, Tafsiran Injil Yohanes Pasal 1-5 Dari Bahasa Yunani (Yogyakarta:Yayasan Andi, 1990), 158.

${ }^{25}$ Robert Kysar, Injil Yohanes Sebagai Cerita (Jakarta: BPK Gunung Mulia, 1995), 20.
} 
Perkataan untuk 'sumur' yang dipergunakan perempuan itu dalam bahasa Yunani phrear menggambarkan tembok bangunan, tapi Yesus dalam ay 14 memakai perkataan untuk 'mata air' dalam bahasa Yunani pege, jadi menggambarkan air itu sendiri. ${ }^{26}$

Air Hidup Ay.10, 11, 13, 14.

Arti ungkapan karunia Allah berasal dari bahasa Yunani dwrea, (dorea) dapat merujuk pada keselamatan (Roma 5:15, 17), Roh Kudus (Kis 2:38 dan 10:45), atau suatu pelayanan atau karunia rohani (Kis. 8:20; 11:17; Ef. 3:7; 4:7). Jelas bahwa istilah ini menekankan unsur gratisan. Dalam konteks ayat ini tampaknya ada kaitan yang erat sekali antara Karunia Allah dan air hidup. ${ }^{27}$

Ketika Yesus berbicara tentang air hidup, wanita Samaria itu menangkap perkataan Yesus hanya secara harfiah, padahal yang dimaksudkan Yesus adalah secara rohaniah juga. Di dalam bahasa sehari-hari orang Yahudi, air hidup berarti air yang sedang mengalir. Yang dimaksud disini adalah air yang mengalir, bukan air yang diam tergenang seperti yang terdapat di kolam atau bak penampungan. Sumur Yakub ini bukanlah sumur yang bermata air, melainkan sumur yang mengumpulkan air yang merembes dari tanah-tanah sekitarnya. Bagi orang Yahudi air hidup, yaitu air yang mengalir dari suatu mata air, jauh lebih baik daripada air yang tergenang. Tetapi orang Yahudi punya pengertian lain lagi tentang air. Mereka sering berbicara tentang jiwa yang haus akan Allah; dan mereka sering berbicara tentang menghilangkan kehausan seperti itu dengan air hidup. ${ }^{28}$ Yesus mengutarakan perbedaan antara air yang menghilangkan haus untuk sementara dan yang dapat menghilangkan haus terus-menerus. Yang terakhir adalah lebih baik, terlebih karena membawa kepada hidup yang kekal. $^{29}$

Air hidup yang hendak Yesus berikan menghasilkan kepuasan dan kebahagiaan kekal (ay.14). Pemberian Yesus jelas tampak lebih berharga ketika dibandingkan dengan hal-hal dari dunia ini, karena tidak ada kesetaraannya sama sekali. "ia tidak akan haus untuk selama-lamanya." Ia tidak akan pernah mencari lagi apa yang akan memuaskan keinginan jiwanya secara berlimpah-limpah.

\footnotetext{
${ }^{26}$ Tafsiran Alkitab Masa Kini 3 (Jakarta: Yayasan Komunikasi Bina Kasih, 1983), 290.

${ }^{27}$ Deve Hagelberg, Tafsiran Injil Yohanes Pasal 1-5 Dari Bahasa Yunani (Yogyakarta:Yayasan Andi, 1990), 160.

${ }^{28}$ Wlliam Barclay, Pemahaman Alkitab Setiap Hari Injil Yohanes Fs. 1-7 (Jakarta: BPK Gunung Mulia, 1983), 258-260.

${ }^{29}$ Tafsiran Alkitab Masa Kini 3 (Jakarta: Yayasan Komunikasi Bina Kasih, 1983), 290.
} 


\section{Respon perempuan Samaria, Ay.15.}

Kata "berilah" dalam bahasa Yunani dos dari kata didomi ${ }^{30}$ yang berarti memberikan. ${ }^{31}$ Bentuk kata kerja yang digunakan aoris imperative aktif orang kedua tunggal. Kata "berilah" dalam ayat ini menjelaskan bahwa pada waktu itu perempuan ini meminta air hidup yang ditawarkan Yesus kepadanya.

Perempuan itu menduga Yesus akan memberinya air dari persediaan Yesus sendiri yang tidak akan pernah habis. Dengan demikian, ia tidak perlu lagi pergi ke sumur itu setiap hari di tengah terik matahari. ${ }^{32}$

Hati yang duniawi, seberapa baik pun keinginan hatinya itu, tidak dapat melihat lebih tinggi daripada tujuan-tujuan duniawi. "Berikanlah itu kepadaku," katanya, "bukan supaya aku memperoleh kehidupan kekal" (seperti yang ditawarkan Kristus), "melainkan supaya aku tidak usah datang lagi ke sini untuk menimba air." 33

Perempuan itu memberikan respon yang baik melalui sikap terbuka yang ditunjukkannya kepada Yesus dengan meminta air yang ditawarkan Yesus kepada-Nya, meskipun permohonannya masih jauh dari keterbukaan rohani yang diharapkan oleh Tuhan Yesus. Respon perempuan ini menunjukkan adanya kemajuan dari sikap sebelumnya meskipun belum memuaskan.

\section{Pengakuan Perempuan Samaria 16-20 Pengakuan Dosa}

Tuhan mau meningkatkan pengertian dan keterbukaan perempuan itu. Untuk itu, Dia mengemukakan masalah suami. Pokok percakapan tidak diubahkan secara sembarangan. Perempuan itu tidak mengerti mengenai air hidup karena dia tidak siap mengakui keadaan rohani yang buruk yang telah menguasai dia. Jika dia menghadapi keadaan rohaninya, maka dia juga dapat mengerti sifat dan kepentingan air hidup yang ditawarkan kepadanya. ${ }^{34}$ Untuk dapat menerima air hidup yang di tawarkan Yesus kepadanya ada masalah penting yang harus diselesaikan perempuan itu dalam hidupnya.

\footnotetext{
${ }^{30}$ dos verb imperative aorist active 2 nd person singular from didomi (BGM Morphology, Word Analysis S. V. “dos” In Bible Work Version 7).

${ }^{31}$ Hasan Susanto, Perjanjian Baru Interlinear Yunani-Indonesia dan Konkordansi Perjanjian Baru (PBIK) Jilid II (Jakarta: LAI, 2003), 206.

${ }^{32}$ Alkitab Edisi Studi (Jakarta: Lembaga Alkitab Indonesia, 2010), 1732.

${ }^{33}$ Matthew Henry, Injil Yohanes 1-11 (Surabaya: Momentum, 2010), 217.

34 Deve Hagelberg, Tafsiran Injil Yohanes Pasal 1-5 Dari Bahasa Yunani (Yogyakarta:Yayasan Andi, 1990), 165.
} 
Yesus berkata kepadanya: "Pergilah, panggillah suamimu, dan datanglah kemari bersama dia." Wanita itu tertegun tegak seolah-olah ada kejutan yang menimpanya; sesungguhnya ia sangat terkejut, sebab tiba-tiba ia menangkap penglihatan tentang dirinya sendiri. Wanita itu tiba-tiba dipaksa untuk melihat dirinya sendiri dan segala ketidak-menentuan, imoralitas dan kekurangan-kekurangan hidup dalam dirinya. Karena melihat sikap dan mendengar kata-kata Yesus yang sebegitu mengesankan, wanita itu rela memberitahukan kepada-Nya tentang kehidupan pribadinya. Diakuinya, ia tidak bersuami. Ia semakin heran ketika Yesus membeberkan masa kini dan masa lalunya secara terperinci dengan menyebut bahwa dia telah berhubungan dengan enam orang lelaki. $^{35}$

\section{Menerima Pengampunan Dosa}

Ayat 18, "Sebab engkau sudah mempunyai lima suami dan yang ada sekarang padamu, bukanlah suamimu. Dalam hal ini engkau berkata benar."

Sementara wanita ini bergumul dengan perasaan-perasaan keinginan dan penarikan diri yang saling bertentangan, Yesus dengan tenang melangkah lebih jauh untuk membuka topeng wanita ini dengan mengarahkan himbauan-Nya kepada rasa moralnya. "Tepat katamu, bahwa engkau tidak mempunyai suami, sebab engkau sudah mempunyai lima suami yang ada sekarang padamu, bukanlah suamimu. Dalam hal ini engkau berkata benar." Dengan menggunakan pengetahuan kenabian-Nya, Yesus membongkar kehidupan pribadinya di hadapan matanya sendiri. ${ }^{36}$ Barulah perempuan itu sadar bahwa ia tidak dapat menyembunyikan apa-apa di hadapan Yesus, yang sudah membuka kedok dari mukanya. Ia berkata, "Tuhan, nyata sekarang padaku, bahwa Engkau seorang nabi." Hatinya ditempelak dan kata-kata itu merupakan suatu pengakuan dosa yang telah diperbuatnya. ${ }^{37}$

\section{Pengakuan Yesus Seorang Nabi}

Ayat 19, "... Tuhan, nyata sekarang padaku, bahwa Engkau seorang nabi.”

Perempuan Samaria ini tidak menyangkal kebenaran dari apa yang Kristus tuduhkan kepadanya, melainkan dengan sikap diamnya itu ia mengakui adilnya teguran itu. Perempuan ini mengakui Kristus sebagai seorang nabi, yang memiliki hubungan dengan sorga.

Kuasa perkataan Kristus dalam menyelidiki hati, dan menyadarkan hati nurani akan dosanya yang tersembunyi, adalah bukti yang sangat

\footnotetext{
${ }^{35}$ Everett F. Harrison, Injil Yohanes Penjelasan Alkitab Untuk Kaum Awam (Jakarta: BPK Gunung Mulia, 1985), 19-20.

${ }^{36}$ Merril C. Tenney, Injil Iman (Malang: Gandum Mas, 1996), 92.

${ }^{37}$ J. Wesley Brill, Tafsiran Injil Yohanes (Bandung: Kalam Hidup, 1976), 51.
} 
kuat bahwa Kuasa-Nya itu berasal dari Allah. (I Kor. 14:24-25). ${ }^{38}$ Ia mengakui segera pengertian Yesus itu dan beranggapan bahwa Ia pastilah seorang nabi untuk dapat mengetahui sedemikian banyak. ${ }^{39}$

Pengenalan perempuan Samaria kepada Yesus mengalami peningkatan dari menganggap Yesus lebih besar dari Yakub menjadi Yesus yang adalah seorang nabi. Tentu saja pengenalan perempuan ini masih jauh dari kesempurnaan tentang pengenalan yang benar bahwa Yesus adalah Tuhan.

\section{Pengajaran Yesus Tentang Penyembahan 21-24 Menyembah apa yang tidak dikenal}

Kata "menyembah" dalam bahasa Yunani prosekunesan dari kata proskuneô ${ }^{40}$ yang berarti menyembah (dengan bersujud), bersujud. ${ }^{41}$ Dan bentuk kata kerja yang digunakan aorist indikatif aktif orang ketiga jamak. ${ }^{42}$ Dalam hal ini, kata menyembah menunjuk kepada oknum yang disembah. Perempuan Samaria menyatakan bahwa mereka (nenek moyang orang Samaria) menyembah di atas gunung Gerizim tetapi mereka tidak mengetahui dengan pasti siapa yang mereka sembah.

Yesus hendak mengajar perempuan itu tentang penyembahan yang benar (ayat 21-24). Lebih dahulu Ia berkata bahwa soal menyembah bukanlah soal tempat. Sia-sialah perdebatan antara orang Yahudi dan orang Samaria mengenai tempat penyembahan. Dalam penyembahan yang benar kepada Bapa tidak ada persoalan mengenai tempat dan syarat-syaratnya. ${ }^{43}$

Ayat 21, “...Percayalah kepada-Ku, hai perempuan, saatnya akan tiba, bahwa kamu akan menyembah Bapa bukan di gunung ini dan bukan juga di Yerusalem."

Sasaran penyembahan kita harus selalu tetap sama, yaitu Allah, sebagai Bapa. Dengan dasar pemikiran inilah orang-orang yang kafir sekalipun menyembah Allah, demikian juga orang-orang Yahudi, dan mungkin pula orang-orang Samaria. Segala pengagungan dan perbedaan tempat ibadah harus diakhiri. Penyembahan Allah sekarang, di bawah Injil, tidak terikat dengan suatu tempat tertentu, seperti yang terjadi di bawah hukum Taurat. Sebaliknya, kehendak Allah supaya manusia bisa

\footnotetext{
${ }^{38}$ Matthew Henry, Injil Yohanes 1-11 (Surabaya: Momentum, 2010), 220.

${ }^{39}$ Tafsiran Alkitab Masa Kini 3 (Jakarta: Yayasan Komunikasi Bina Kasih, 1983), 290.

${ }^{40}$ prosekunesan verb indicative aorist active $3 \mathrm{rd}$ person plural from proskuneô (BGM Morphology, Word Analysis s.v.. "prosekunesan” In Bible Work Version 7).

${ }^{41}$ Hasan Susanto, Perjanjian Baru Interlinear Yunani-Indonesia dan Konkordansi Perjanjian Baru (PBIK) Jilid II (Jakarta: LAI, 2003), 678. (bersujud dapat menunjuk tanda hormat, takut, atau memohon sesuatu kepada manusia yang dianggap dari dunia supernatural).

${ }^{42}$ Kata "aoris" berarti "tak terdefinisikan," "tak tentu."

${ }^{43}$ J. Wesley Brill, Tafsiran Injil Yohanes (Bandung: Kalam Hidup, 1976), 51.
} 
beribadah di mana saja (I Tim 2:8; Mal. 1:1). Saatnya akan tiba bahwa tidak akan ada lagi perbedaan demikian dalam pandangan Allah, tidak juga antara Yerusalem yang pernah sangat terkenal dengan kekudusannya dengan gunung di Samaria yang pernah sangat tidak disukai karena ketidaksalehannya. ${ }^{44}$

Ayat 22a, "Kamu menyembah apa yang tidak kamu kenal."

Pengenalan mereka akan Allah yang mereka sembah sangat terbatas, mungkin karena mereka menolak Kitab Yosua sampai dengan Kitab Maleakhi. Memang mereka menerima kelima Kitab Musa, Kejadian sampai dengan Ulangan, maka dapat dikatakan bahwa mereka menyembah Allah Abraham, Ishak, dan Yakub, namun mereka tidak mengenal Dia. ${ }^{45}$

Kamu menyembah apa yang tidak kamu kenal, atau apa yang tidak kamu ketahui. Mereka menyembah Allah Israel, Allah yang sejati (Ezr. 4:2; 2Raj. 17:32), namun mereka tenggelam dalam ketidaktahuan yang besar. Mereka menyembah Dia sebagai Allah negeri itu (2Raj. 17:27, 33), sebagai dewa setempat, seperti para allah bangsa-bangsa, padahal Allah harus disembah sebagai Allah, sebagai pencipta alam semesta dan Tuhan. Kebodohan tidak mungkin dapat melahirkan ibadah yang benar, justru membinasakannya. Mereka yang menyembah Allah dalam kebodohan sama seperti mempersembahkan korban yang buta, dan ini adalah korban orang-orang bodoh. ${ }^{46}$

\section{Menyembah Apa Yang di Kenal}

Orang Yahudi memiki penyataan yang jauh lebih lengkap, karena orang Samaria membatasi dirinya kepada Pentateukh. Karena "apa" adalah dipakai maka perhatian dipusatkan terutama kepada hekekat daripada pribadi yang menjadi sasaran ibadah. ${ }^{47}$ Di sini Yesus menggunakan kata oidamen ${ }^{48}$ dalam bentuk kata kerja indicative perfect active,

\footnotetext{
${ }^{44}$ Matthew Henry, Injil Yohanes 1-11 (Surabaya: Momentum, 2010), 224.

${ }^{45}$ Keadaan mereka dapat dibandingkan dengan keadaan orang kafir, orang yang tidak menerima Firman Allah, yang diceritakan dalam Kis. 17:23, yang berbunyi, "Sebab ketika aku berjalan-jalan di kotamu dan melihat-lihat barang-barang pujaanmu, aku menjumpai juga sebuah mezbah dengan tulisan: Kepada Allah yang tidak dikenal. Apa yang kamu sembah tanpa mengenalnya, itulah yang kuberitakan kepada kamu." Deve Hagelberg, Tafsiran Injil Yohanes Pasal 1-5 Dari Bahasa Yunani (Yogyakarta:Yayasan Andi, 1990), 169-170.

${ }^{46}$ Matthew Henry, Injil Yohanes 1-11 (Surabaya: Momentum, 2010), 225.

${ }^{47}$ Tafsiran Alkitab Masa Kini 3 (Jakarta: Yayasan Komunikasi Bina Kasih, 1983), 290.

48“oidamen" dalam bentuk verb indicative perfect active 1st person plural yang berasal dari kata "oida" yang berarti mengenal (BGM Morphology, Word Analysis s.v. "oidamen" In Bible Work Version 7).
} 
untuk menunjukkan bahwa orang Yahudi menyambah Allah yang mereka kenal pada masa lampau dan terus berlangsung sampai saat ini yang membuat mereka tetap tinggal di dalam pengenalan yang benar akan siapa Allah yang mereka sembah.

Keselamatan datang dari bangsa Yahudi, kata Yesus, bukan karena bangsa Yahudi memiliki bait Allah yang benar, tetapi karena Mesias datang dari tengah-tengah bangsa itu. Hal ini disetujui oleh orang-orang Samaria. Dalam Kejadian 49:10 bapak-leluhur Yakob katakan kepada Yehuda, bahwa "tongkat kerajaan tidak akan beranjak dari keturunannya" dan bahwa "lambang pemerintahan tidak akan beranjak dari antara kakinya", sampai "datang dia, yang berhak atasnya". ${ }^{4}$

\section{Penyembah-penyembah Yang Benar}

Tetapi saatnya sudah tiba sekarang, kata ini membawa pada apa yang dikatakan sebelumnya dalam ayat 21 menjadi berlaku pada waktu sekarang. Tidak ada suatu apapun yang merintangi orang sekarang, Yahudi atau Samaria, untuk menyembah dalam Roh dan Kebenaran.

Di sini Yesus menggunakan kata alethinoi dari kata alethinos ${ }^{50}$ yang berarti sejati. ${ }^{51}$ Sehingga dalam konteks ini yang dimaksudkan dengan kebenaran atau sejati ialah sesuatu yang sama sekali tidak terkontaminasi dengan dosa apapun, dengan kata lain bahwa seseorang harus hidup suci atau kudus. Kata "penyembah-penyembah" dalam bahasa aslinya proskunetai dari kata proskunetes ${ }^{52}$ yang berarti penyembah. ${ }^{33}$ Arti kata "penyembah" secara harfiah ialah "orang yang menyembah" 54 Dalam hal ini Yesus mengatakan bahwa telah tiba waktunya orang-orang yang yang menyembah dengan hati yang murni dalam arti telah disucikan akan menyembah Allah dalam roh dan kebenaran.

Penyembah-penyembah yang benar adalah orang-orang Kristen yang baik, yang berbeda dari orang-orang munafik. Mereka semua harus dan akan menyembah Allah dalam roh dan kebenaran. ${ }^{55}$ Yesus

\footnotetext{
${ }^{49}$ J.L.Ch.Abineno, Yesus Sang Mesias dan Sang Anak (Jakarta: BPK Gunung Mulia, 1999), 76

${ }^{50}$ alethinoi adjective normal nominative masculine plural no degree from alethinos (BGM Morphology, Word Analysis s.v. “alethinoi.” In Bible Work Version 7).

${ }^{51}$ Hasan Susanto, Perjanjian Baru Interlinear Yunani-Indonesia dan Konkordansi Perjanjian Baru (PBIK) Jilid II (Jakarta: LAI, 2003), 45.

${ }^{52}$ proskunetai noun nominative masculine plural common from proskunetes (BGM Morphology, Word Analysis S. V. "proskunetai” In Bible Work Version 7).

${ }^{53}$ Hasan Susanto, Perjanjian Baru Interlinear Yunani-Indonesia dan Konkordansi Perjanjian Baru (PBIK) Jilid II (Jakarta: LAI, 2003), 679.

${ }^{54}$ Kamus Besar Bahasa Indonesia, s.v. "penyembah"

${ }^{55}$ Matthew Henry, Injil Yohanes 1-11 (Surabaya: Momentum, 2010), 229.
} 
menyatakan bahwa penyembah yang benar tidak bergantung pada tempat tertentu untuk beribadat. Ibadat yang benar terjadi tatkala orang dipimpin oleh Roh Allah. ${ }^{56}$

Dihubungkannya roh dan kebenaran memberi terang atas makna "penyembah-penyembah yang benar." Ini adalah orang-orang yang benar-benar berbakti, berbeda dari mereka yang hanya tampaknya saja berbakti dengan ikut dalam upacara-upacara lahiriah. Tekanan utama ialah atas "roh" sebagaimana tampak dalam ayat yang berbunyi "sebab Bapa menghendaki penyembah-penyembah demikian." Penyebab asasi mengapa ibadah yang benar harus rohaniah terdapat dalam sifat Allah. Ia mencari penyembah-penyembah yang benar yang terdiri dari mereka yang bersesuaian dengan sifat- $\mathrm{Nya}^{5}{ }^{5}$

Karena kerinduan hati Allah Bapa, maka hal-hal seperti tempat ibadah, yaitu apa yang lahiriah, tidak berarti dan tidak relevan dengan hubungan kita dengan Allah. Yang penting ialah sikap hati kita. Dengan berkata bahwa penyembah-penyembah benar akan menyembah Bapa dalam roh dan kebenaran, Tuhan Yesus juga menolak kesalahan ajaran mereka di Samaria. Unsur kebenaran juga tidak dapat diabaikan. Mereka salah dalam beberapa pokok ajaran, dan hal itu juga ditegur. ${ }^{58}$

\section{Menyembah dalam roh dan kebenaran}

Ayat 24, "Allah itu Roh dan barangsiapa menyembah Dia, harus menyembahNya dalam roh dan kebenaran."

Penggunaan kata "roh" di sini menggunakan huruf kecil. Karena itu kata "roh" yang dimaksudkan di sini bukanlah "Roh Tuhan" itu sendiri yang kita sembah melainkan yang dimaksudkan dengan penggunaan kata "roh" disini ialah roh manusia. Sehingga menyembah dalam "roh" dapat diartikan bahwa manusia harus memiliki suatu hubungan yang terus menerus "di dalam alam roh" sebagai sikap seseorang yang bukan menyembah dalam keadaan tubuh yang jasmani melainkan ia membawa seluruh hidupnya untuk datang menyembah Allah dengan sepenuh hati dan jiwanya, sebab Allah adalah Roh sehingga manusia harus menyembah-Nya dalam roh. Selain itu penggunaan kata "kebenaran" dalam kamus besar bahasa Indonesia berarti sesuatu yg sungguh-sungguh, keadaan yang sungguh-sungguh atau kelurusan hati. Karena itu menyembah dalam kebenaran dapat diartikan bahwa seseorang yang bukan sekedar menyembah dengan sungguh-sungguh

\footnotetext{
${ }^{56}$ Alkitab Edisi Studi (Jakarta: Lembaga Alkitab Indonesia, 2010), 1733.

${ }^{57}$ Tafsiran Alkitab Masa Kini 3 (Jakarta: Yayasan Komunikasi Bina Kasih, 1983), 290-291.

${ }^{58}$ Deve Hagelberg, Tafsiran Injil Yohanes Pasal 1-5 Dari Bahasa Yunani (Yogyakarta:Yayasan Andi, 1990), 171, 173.
} 
atau dengan hati yang tulus melainkan suatu sikap hormat kepada Tuhan yang dilakukan terus-menerus dengan kepenuhan hati yang sungguh-sungguh kepada-Nya.

Allah adalah Roh. Karena itu siapa yang menyembah-Nya, harus menyembah-Nya dalam roh dan kebenaran. "Roh" adalah sebaliknya dari "daging". Apa yang dilahirkan dari daging, adalah daging, dan apa yang dilahirkan dari Roh, adalah roh, demikian kata Yesus kepada Nikodemus (3:6). Penyembah-penyembah yang benar harus mempunyai sesuatu seperti Natanael: seorang, yang dalamnya "tidak ada kepalsuan" $(1: 47)^{59}$

Allah harus disembah dalam roh dan kebenaran, memiliki dua dasar teologis: pertama, karena Allah Bapa merindukan para penyembah demikian, dan kedua, karena Allah sendiri adalah Roh, dan bukan daging. Jelaslah, bahwa Allah yang Roh adanya, tidak boleh disembah jika bukan dalam roh kita. ${ }^{60}$

\section{Yesus Menyatakan Diri Sebagai Mesias}

Ayat 25-26, "Jawab perempuan itu kepada-Nya: Aku tahu, bahwa Mesias akan datang, yang disebut juga Kristus; apabila Ia datang, Ia akan memberitakan segala sesuatu kepada kami. Kata Yesus kepadanya: Akulah Dia, yang sedang berkata-kata dengan engkau."

Tanggapan perempuan itu terhadap Yesus menunjukkan bahwa ia mulai melihat Yesus lebih dari sekadar seorang Yahudi atau seorang nabi. Sesuatu yang "lebih" itu tidak membuat perempuan itu menjadi menutup diri, tetapi membawanya memunculkan satu hal penting mengenai pengharapan mesianisnya, "Aku tahu, bahwa Mesias akan datang" (bagi para pembaca yang tidak memahami makna istilah Yahudi itu, Yohanes menulis bahwa Mesias itu "disebut juga Kristus"). "Apabila Ia datang, Ia akan memberitakan segala sesuatu kepada kami".

Kata-kata ini sekaligus merupakan pengakuan akan ketidaktahuan dan pengharapan. Wanita ini sedang menunggu terang, dan walaupun ternoda, ia bergantung kepada janji Allah dari purbakala bahwa seorang pelepas akan datang dan membuang kegelapan dari matanya. ${ }^{62}$ 1999), 76

${ }^{59}$ J.L.Ch.Abineno, Yesus Sang Mesias dan Sang Anak (Jakarta: BPK Gunung Mulia,

${ }^{60}$ Penampilan pemimpin-pemimpin agama Samaria cukup mantap: dari segi apa yang Nampak di depan umum mereka cukup suci dan agamawi. Namun mungkin perempuan itu sudah tahu mengenai kemunafikan mereka, mungkin lewat kata teman atau pengalaman sendiri. Deve Hagelberg, Tafsiran Injil Yohanes Pasal 1-5 Dari Bahasa Yunani (Yogyakarta:Yayasan Andi, 1990), 173. 2009), 32.

${ }^{61}$ Michael H. Crosby, Apakah Engkau Mengasihi Aku? (Jakarta: BPK Gunung Mulia,

${ }^{62}$ Merril C. Tenney, Injil Iman (Malang: Gandum Mas, 1996), 92. 
Reaksi wanita Samaria itu mengejutkan. Pada permulaan percakapan mereka ia berkata kepada Yesus: "Apakah Engkau lebih besar daripada bapak-leluhur kami Yakub?" (4:12). Kemudian ia menarik kesimpulan: "Nyata sekarang padaku, bahwa tuan adalah seorang nabi" (4:19). Dan sekarang ia mengungkapkan dugaannya, bahwa Yesus mungkin adalah Mesias yang disebut Kristus: "Ia akan memberitakan segala sesuatu kepada kami" (4:25). Ungkapan ini sesuai dengan pengharapan orang-orang Samaria akan kedatangan Tabib (Mesias) yang akan memberitakan kebenaran dan yang akan berfungsi sebagai nabi seperti Musa. ${ }^{63}$

"Akulah Dia, yang sedang berkata-kata dengan Engkau." Tidak ada keseganan saat ini pada Yesus untuk mengaku bahwa Dialah Mesias itu, sekalipun Injil-injil Sinoptis sering mencatat keseganan demikian. Tidak ada kekuatiran akan akibat-akibat politis ketika Yesus bersama orangorang Samaria sebagaimana ada bila Ia terdapat di kalangan orang-orang Yahudi. Hal ini cukup menerangkan pendekatan yang berbeda itu. Di sini kita temukan penyataan pribadi dari Mesias kepada seorang yang memiliki suatu pengharapan dan karena itu bersiap untuk menerima penyataan sedemikian ini. ${ }^{64}$

Karena perempuan itu sudah membuka hatinya, maka akhirnya dengan segala kelemahlembutan Tuhan Yesus mengaku bahwa Dialah Mesias. Pengakuan yang istimewa dan mulia ini dibentuk dengan nada yang begitu lemah lembut. Kasih-Nya kepada perempuan itu, dan seluruh desa Sikhar, nyata dalam kalimat itu. Kemungkinan besar, perempuan itu tidak menangkap kaitan ungkapan Akulah Dia dengan nama Allah, tetapi orang yang membaca Injil Yohanes berkali-kali mengerti bahwa dalam ayat ini Tuhan Yesus mengaku diri-Nya sebagai Mesias secara terang-terangan, dan Dia memberi petunjuk bahwa Dia adalah Allah. ${ }^{65}$

Kesaksian Perempuan Samaria (28-30)

\section{Pergi Ke Kota}

Ayat 28, "Maka perempuan itu meninggalkan tempayannya di situ lalu pergi ke kota dan berkata kepada orang-orang yang ada di situ."

Sesudah percakapan ini wanita Samaria itu pergi ke kota. Perempuan itu melupakan tempayannya. Yang ia pikirkan hanyalah "air hidup", yang sementara itu telah ia terima. Perempuan yang selama ini

${ }^{63}$ J.L.Ch.Abineno, Yesus Sang Mesias dan Sang Anak (Jakarta: BPK Gunung Mulia, 1999), 76-77.

${ }^{64}$ Tafsiran Alkitab Masa Kini 3 (Jakarta: Yayasan Komunikasi Bina Kasih, 1983), 291.

${ }^{65}$ Deve Hagelberg, Tafsiran Injil Yohanes Pasal 1-5 Dari Bahasa Yunani

(Yogyakarta:Yayasan Andi, 1990), 176-177. 
dijauhi oleh bangsanya, sekarang menjadi wanita yang membawa mereka kepada Yesus. Perempuan ini gembira bahwa kepadanya Yesus mengatakan segala sesuatu, yang telah ia lakukan. Hal itu diusahakan juga oleh orang-orang lain, tetapi tidak ada dari usaha-usaha itu yang dapat menolongnya, sebab apa yang mereka lihat ialah hanya segi-segi yang negatif saja dari hidupnya.

Mereka sangat berbeda dengan Yesus. Yesus bukan saja mengetahui latarbelakangnya, Ia juga mengertinya. Karena itu Ia berbicara atas jalan yang lain sekali tentang hidupnya daripada yang biasa ia dengar. ${ }^{66}$

Perempuan itu meninggalkan tempayannya supaya dia dapat tiba lebih cepat di kota, untuk mengantarkan kabar baik ini ke sana. Barang siapa bertugas untuk mewartakan nama Kristus tidak boleh membebani atau merepotkan diri mereka dengan segala sesuatu yang akan menghambat atau mencegah mereka melakukannya. Ketika para murid hendak dijadikan penjala manusia, mereka harus meninggalkan segala sesuatu. ${ }^{67}$

\section{Bersaksi Tentang Kristus}

Ajakan perempuan itu kepada orang-orang sekotanya, "Mari, lihat!" menggemakan ucapan pertama Yesus kepada murid-murid-Nya (1:46). Fakta bahwa Yohanes menempatkan ucapan Yesus pada mulut perempuan itu menunjukkan bahwa ia memandang perempuan itu sebagai murid yang benar. Meski fakta mengatakan bahwa Yesus menyingkapkan diri perempuan itu yang sebenarnya, Ia melakukannya dengan sebuah cara penebusan yang membuatnya menjadi percaya. ${ }^{68}$

Usaha perempuan itu sebagai orang berdosa tidak dihalangi oleh reputasinya. Malah, reputasinya menjadi unsur dalam pemberitaannya: "Dia telah mengatakan kepadaku segala sesuatu yang telah kuperbuat." Orangorang desa Sikhar disiapkan untuk menerima air kehidupan, yang tidak mereka pahami, dan murid-murid Tuhan Yesus disiapkan untuk bekerja untuk makanan yang tidak mereka pahami, yaitu melakukan kehendak Allah, membawa calon penyembah-penyembah dalam roh dan kebenaran kepada Allah. ${ }^{69}$

\footnotetext{
${ }^{67}$ Matthew Henry, Injil Yohanes 1-11 (Surabaya: Momentum, 2010), 237.

${ }^{68}$ Michael H. Crosby, Apakah Engkau Mengasihi Aku? (Jakarta: BPK Gunung Mulia, 2009), 33

${ }^{69}$ Deve Hagelberg, Tafsiran Injil Yohanes Pasal 1-5 Dari Bahasa Yunani

(Yogyakarta:Yayasan Andi, 1990), 182-183.
} 1999), 77

${ }_{77}^{66}$.L.Ch.Abineno, Yesus Sang Mesias dan Sang Anak (Jakarta: BPK Gunung Mulia, 
"Dia mengatakan kepadaku segala sesuatu yang telah ku perbuat". Tak ada yang dicatat selain apa yang dikatakan-Nya mengenai suami-suami perempuan itu; namun bukan tidak mungkin bahwa Dia telah memberitahukan kepada perempuan itu lebih banyak lagi kesalahannya. Atau, apa yang disampaikan Yesus itu, bagi dia, tidak mungkin diketahui Yesus dengan cara-cara biasa, dan hal ini sungguh meyakinkan dirinya bahwa Yesus bisa saja memberitahukan segala sesuatu yang lain yang telah diperbuatnya.

Jika Dia memiliki pengetahuan ilahi, maka Dia pasti tahu segala sesuatu. Yesus mengatakan kepadanya apa yang tidak diketahui oleh seorang pun kecuali Allah dan perempuan itu sendiri. ${ }^{70}$

Tindakan spontan dari wanita Samaria itu ialah menuturkan semua hal yang ia lihat dan alami itu. Setelah bertemu dengan pribadi yang mengherankan itu, wanita tersebut merasa dipaksa untuk menuturkan segala yang dialaminya kepada orang lain. Kehidupan Kristen itu didasarkan pada dua soko-guru kembar, yaitu menemukan dan menuturkan.

Dalam ayat 19, ia menyebutnya nabi, karena tidak ada cara lain untuk menjelaskan pengetahuan-Nya tentang kehidupannya. Akhirnya, dalam ayat 29, di antara orang-orang sekotanya ia berkata, "Tidakkah kamu berpikir bahwa inilah Mesias?" Perempuan ini terlalu berhati-hati untuk menegaskan secara pasti bahwa penilaiannya benar, tetapi bahasanya menyiratkan bahwa tidak ada sedikit pun keraguan dalam pikirannya. $^{71}$

\section{Orang-orang Yang Mendengar Kesaksian Datang Kepada Yesus}

Ayat 30, "Maka merekapun pergi ke luar kota lalu datang kepada Yesus."

Meskipun sepertinya sangat tidak mungkin bahwa sosok perempuan yang begitu tidak berarti, dan begitu buruk sifatnya, akan mendapat kehormatan untuk menjadi orang pertama di antara penduduk Samaria yang bertemu dengan Mesias, namun Allah dengan senang menggerakkan hati orang-orang itu untuk mendengar kabar yang dibawanya, dan tidak menganggapnya sebagai omong kosong belaka.

Begitu juga halnya ketika para penderita kusta merupakan orang pertama yang membawa kabar baik ke Samaria mengenai pembebasan besar-besaran (2Raj. 7:3, dst.). Mereka datang kepada Yesus. Bukannya mengundang Dia untuk datang kepada mereka di kota, namun sebagai tanda penghormatan mereka kepada-Nya, dan kesungguhan hasrat mereka untuk melihat-Nya, maka mereka pergi keluar mendatangi-Nya.

\footnotetext{
${ }^{70}$ Matthew Henry, Injil Yohanes 1-11 (Surabaya: Momentum, 2010), 239.

${ }^{71}$ Merril C. Tenney, Injil Iman (Malang: Gandum Mas, 1996), 93.
} 
Mereka yang ingin mendengar Kristus harus menjumpainya di mana Dia memperdengarkan nama-Nya. ${ }^{72}$

Orang-orang Samaria tidak diikat oleh berbagai aturan agama Yahudi yang berkaitan dengan sikap terhadap kaum perempuan di tempat umum, dalam agama, dalam hokum. Betapa pun rendahnya kedudukan perempuan Samaria itu di mata beberapa orang Yahudi yang menyangsikan kesaksiannya, perempuan tersebut tidak mengalami tentangan dari penduduk kota (4:28-30). Ini artinya kesaksiannya cukup dapat meyakinkan mereka untuk percaya kepadanya. ${ }^{73}$ Kesaksian perempuan itu berhasil, mereka datang kepada Yesus. Murid-muridNya membawa roti, tetapi perempuan ini membawa manusia. ${ }^{74}$

\section{Percakapan Yesus Dengan Murid-Murid-Nya (31-38)}

Ayat 31-38 menceritakan dua macam makanan, dan dua macam panen. Ada makanan jasmani dan rohani, dan ada panen jasmani dan rohani. Yang jasmani dipakai oleh Tuhan Yesus untuk menceritakan yang rohani (sama seperti kelahiran dalam pasal 3:1-13, dan air dalam pasal 4:5-15!)..$^{75}$

Ia mengatakan sesuatu yang mempunyai makna rohani. Mulamula perkataannya itu ditangkap secara harafiah tanpa pengertian yang tepat, tetapi kemudian Yesus secara sedikit demi sedikit menyatakan artinya yang benar sampai pendengarnya mengerti secara betul. ${ }^{76}$

\section{Makanan Jasmani dan Makanan Rohani (31-34)}

Ayat 31, "Sementara itu murid-murid-Nya mengajak Dia, katanya: Rabi, makanlah."

Sesudah perjalanan yang begitu jauh, mereka semua haus dan lapar. Namun mereka tidak mungkin makan sebelum Rabi mereka makan, maka mereka sungguh berharap supaya Dia makan. Mereka memikirkan kebutuhan jasmani, sedangkan Tuhan Yesus memikirkan kebutuhan yang lain, yang dimiliki para penghuni kota kecil itu di

\footnotetext{
${ }^{72}$ Matthew Henry, Injil Yohanes 1-11 (Surabaya: Momentum, 2010), 241.

${ }^{73}$ Michael H. Crosby, Apakah Engkau Mengasihi Aku? (Jakarta: BPK Gunung Mulia, 2009), 33.

${ }^{74}$ Deve Hagelberg, Tafsiran Injil Yohanes Pasal 1-5 Dari Bahasa Yunani (Yogyakarta:Yayasan Andi, 1990), 182-183.

${ }^{75}$ Ibid.

${ }^{76}$ William Barclay, Pemahaman Alkitab Setiap Hari Injil Yohanes Fs. 1-7 (Jakarta: BPK Gunung Mulia, 1983), 279.
} 
Samaria. Oleh karena itu, murid-murid-Nya harus belajar mengenai makanan yang tidak mereka pahami, sama seperti perempuan itu telah belajar mengenai air yang tidak dia bayangkan. ${ }^{77}$

Ayat 32, "Akan tetapi Ia berkata kepada mereka: PadaKu ada makanan yang tidak kamu kenal."

Selaku jawab terhadap suguhan makanan, Yesus mengalihkan pembicaraan kepada persoalan-persoalan rohani. PadaKu ada makanan yang tidak kamu kenal. Kedua kata ganti itu (Aku; kamu) punya tekanan dan menarik perhatian atas perbedaan besar antara Yesus dan muridmurid-Nya. ${ }^{78}$

Peristiwa yang kecil ini sebenarnya menyatakan prioritas Tuhan Yesus. Walaupun lapar, Dia menunda acara makan siang demi kepentingan penginjilan (dan latihan buat murid-murid-Nya). Karena kehendak Allah, yang tampaknya baru dinyatakan melalui situasi, acara puasa dan penginjilan menggantikan acara makan siang. Dengan demikian kita melihat bahwa Dia mengutamakan acara rohani, dan Dia lunak dalam hal jadwal. ${ }^{79}$

Ayat 34, "Kata Yesus kepada mereka: MakananKu ialah melakukan kehendak Dia yang mengutus Aku dan menyelesaikan pekerjaan-Nya."

Berdasarkan ayat diatas seolah-olah Yesus berkata, "Ada perasaan lapar yang lebih penting daripada perasaan lapar karena makanan; dan ada makanan yang dapat memuaskan lapar itu. Aku sedang makan makanan itu, yakni melakukan kehendak Allah, memimpin seorang perempuan kepada Terang dunia dan menarik perempuan berdosa itu sehingga percaya kepada Juruselamat dunia." Yesus bersukacita karena perempuan yang diselamatkan itu bagaikan roti bagi jiwa-Nya. ${ }^{80}$

Sampai titik ini, dan seterusnya juga, tema iman sering ditekankan dalam Injil Yohanes. Perempuan itu baru percaya, dan dia akan membawa orang lain kepada Tuhan Yesus supaya mereka juga dapat percaya. Melayani mereka adalah kehendak Dia yang mengutus Tuhan Yesus, maka Dia membentuk suatu kiasan mengenai hal itu. Sama seperti orang disegarkan dengan makan makanan biasa, Dia disegarkan dengan melakukan kehendak Allah. ${ }^{81}$

\footnotetext{
77 Deve Hagelberg, Tafsiran Injil Yohanes Pasal 1-5 Dari Bahasa Yunani (Yogyakarta:Yayasan Andi, 1990), 183-184.

${ }^{78}$ Tafsiran Alkitab Masa Kini 3 (Jakarta: Yayasan Komunikasi Bina Kasih, 1983), 291.

79 Deve Hagelberg, Tafsiran Injil Yohanes Pasal 1-5 Dari Bahasa Yunani (Yogyakarta:Yayasan Andi, 1990), 184.

${ }^{80} \mathrm{~J}$. Wesley Brill, Tafsiran Injil Yohanes (Bandung: Kalam Hidup, 1976), 52.

${ }^{81}$ Deve Hagelberg, Tafsiran Injil Yohanes Pasal 1-5 Dari Bahasa Yunani (Yogyakarta:Yayasan Andi, 1990), 185.
} 


\section{Panen Jasmani dan Panen Rohani (35-38)}

Ayat 35, “... empat bulan lagi tibalah musim menuai? Tetapi Aku berkata kepadamu: Lihatlah sekelilingmu dan pandanglah lading-ladang yang sudah menguning dan matang untuk dituai."

Mereka berkata, "Musim menuai masih empat bulan lagi, sekarang belum waktunya." Tempat atau negeri yang seakan-akan belum siap untuk penginjilan sebenarnya sudah siap jikalau orang-orang mau menuainya. Bukan ladangnya yang tidak siap untuk dituai, melainkan penuainya belum siap bekerja. ${ }^{82}$

Yang menentukan waktu penuaian ialah kedatangan Mesias. Oleh kedatangan-Nya itu mulailah waktu penuaian, di mana murid-murid mengumpulkan tuaian dari apa yang tidak mereka tabur. Yesus adalah penabur dan murid-murid-Nya adalah penuai-penuai. Sama-sama mereka bersukacita karena tuaian yang sedang menanti. ${ }^{83}$

Ayat 36-37, "Penuai telah menerima upahnya dan ia mengumpulkan buah untuk hidupyang kekal."

"Buah itu dikumpulkan untuk hidup yang kekal." Ini adalah penghiburan bagi para pelayan yang setia, karena ternyata pekerjaan mereka memiliki tujuan untuk keselamatan kekal bagi jiwa-jiwa yang berharga. "Penabur dan penuai sama-sama bersukacita."

Pelayan yang beruntung menjadi alat untuk memulai suatu pekerjaan yang baik adalah penabur, seperti Yohanes Pembabtis. Orang yang dipekerjakan untuk melanjutkan pekerjaan itu dan menyempurnakannya adalah penuai: dan keduanya sama-sama bersukacita. ${ }^{84}$ Yang menabur adalah mereka yang memberitakan amanat Allah kepada orang lain; yang menuai adalah mereka yang membantu orang lain untuk percaya kepada Yesus. ${ }^{85}$

Dengan demikian baik penabur (yaitu perempuan itu, yang telah berbicara dengan warga Sikhar) maupun penuai (yaitu murid-murid Yesus, jika mereka rela menunda makan) dapat sama-sama bersukacita. Ada sukacita yang lebih baik dari sukacita makan. Tuhan Yesus sudah biasa menikmati sukacita itu, dan Dia mau mengajak murid-murid-Nya untuk menikmatinya juga. ${ }^{86}$

\footnotetext{
${ }^{82}$ J. Wesley Brill, Tafsiran Injil Yohanes (Bandung: Kalam Hidup, 1976), 52.

${ }^{83}$ J.L.Ch.Abineno, Yesus Sang Mesias dan Sang Anak (Jakarta: BPK Gunung Mulia, 1999), 78.

${ }^{84}$ Matthew Henry, Injil Yohanes 1-11 (Surabaya: Momentum, 2010), 249.

${ }^{85}$ Alkitab Edisi Studi (Jakarta: Lembaga Alkitab Indonesia, 2010), 1733.

${ }^{86}$ Deve Hagelberg, Tafsiran Injil Yohanes Pasal 1-5 Dari Bahasa Yunani (Yogyakarta:Yayasan Andi, 1990), 188.
} 
Ayat 38, "Aku mengutus kamu untuk menuai apa yang tidak kamu usahakan; orang-orang lain berusaha dan kamu datang memetik hasil usaha mereka."

Walaupun mereka sudah sekian lama mengikuti Tuhan Yesus, barulah dalam nas ini kita membaca, mereka diberitahu bahwa, mereka diutus untuk melakukan suatu tugas. Mereka harus mengerti bahwa hasil usaha yang mereka petik, dapat mereka petik, karena pelayanan orang-orang lain yang mendahului mereka. ${ }^{87}$

"Aku mengutus kamu untuk menuai." Yesus mengingatkan para murid bahwa pengalaman-pengalaman mereka yang baru lalu dan yang sekarang, berhutang budi pada pekerjaan-pekerjaan orang lain.

Istilah untuk pekerjaan adalah perkataan yang digunakan untuk pekerjaan keras. "Orang-orang lain" kepada siapa Yesus meng-unjuk, adalah mereka yang telah menyediakan jalan bagi Kristus. Prinsip ini berarti bahwa tidak ada seseorang pribadi yang dapat menuntut seluruh kehormatan dalam misi rohani. ${ }^{88}$

\section{Hasil Penginjilan (39-42)}

"Banyak orang" percaya kepada-Nya karena kesaksian perempuan itu (4:39). "Melalui kesaksiannya", tujuannya untuk membawa orangorang lain datang kepada Kristus mulai terwujud.

"Orang banyak" datang kepada Yesus karena perkataan perempuan itu. Sekarang mereka percaya kepada-Nya, bukan lagi karena kesaksiannya, melainkan pengalaman mereka sendiri. Mereka mendengarkan Dia yang telah menuntun mereka untuk mengenal bahwa Dialah "Juruselamat yang sesungguhnya". 89

\footnotetext{
${ }^{87}$ Morris (hlm. 281-282) mencoba memastikan dalam kasus ini, hasil usaha siapa yang dipetik oleh murid-muridNya. Ternyata sulit memastikannya, mungkin karena Tuhan Yesus memberi suatu perinsip umum, dan mereka memetik hasil usaha banya orang, termasuk Tuhan Yesus sendiri, perempuan Samaria itu, Yohanes Pembaptis serta pengikutnya, dan nabi-nabi dari dahulu kala. Deve Hagelberg, Tafsiran Injil Yohanes Pasal 1-5 Dari Bahasa Yunani (Yogyakarta:Yayasan Andi, 1990), 188.

${ }^{88}$ Tafsiran Alkitab Masa Kini 3 (Jakarta: Yayasan Komunikasi Bina Kasih, 1983), 292.

${ }^{89}$ Michael H. Crosby, Apakah Engkau Mengasihi Aku? (Jakarta: BPK Gunung Mulia,
} 2009), 34 . 


\section{IMPLEMENTASI MODEL PENGINJILAN DALAM KEHIDUPAN ORANG PERCAYA PADA MASA KINI}

\section{Model Penginjilan Yesus}

Model penginjilan Yesus kepada seorang perempuan Samaria merupakan contoh yang baik untuk diteladani, supaya Injil dapat diberitakan kepada mereka yang belum percaya, model ini masih relevan di segala zaman dan dapat digunakan sesuai dengan keperluannya. Untuk itu, Model penginjilan Yesus ini, penulis akan uraikan, sebagai berikut:

\section{Keluar Dari Zona Nyaman}

Yesus adalah seorang Yahudi. Dalam bab-bab sebelumnya telah dibahas bahwa orang Yahudi tidak bergaul dengan orang Samaria. Tetapi Yesus melintasi daerah Samaria, di mana sebagian besar orang Yahudi lebih memilih untuk tidak melintasi daerah itu dan mengambil jalan yang memakan waktu perjalanan lebih jauh dibandingkan dengan melintasi daerah Samaria, karena mereka berpikir bahwa mereka lebih baik dari pada orang-orang Samaria. Yesus berbeda, Ia tidak seperti orang-orang Yahudi kebanyakan yang tetap memasang tembok penghalang dengan orang Samaria dan tetap tetap tinggal dalam zona nyaman mereka dalam keadaan seperti itu. Yesus meruntuhkan semua perbedaan itu dengan cara keluar dari zona nyaman untuk mencari jiwa yang terhilang di Samaria. Ia tidak mempedulikan prasangka-prasangka apa yang akan muncul atau apa yang akan dikatakan orang-orang Yahudi ketika Ia melintasi Samaria, yang Ia tahu adalah Dia ingin melakukan kehendak Bapa-Nya untuk mencari domba yang hilang di Samaria.

Sebagai orang percaya yang telah hidup dalam keselamatan yang dianugerahkan Allah, kita wajib memberitakan kabar baik ini kepada orang-orang yang belum percaya agar mereka juga beroleh keselamatan dalam hidup mereka. Tetapi, tidak banyak orang percaya yang sadar akan hal ini. Mereka cenderung tinggal dalam zona nyaman mereka dan tidak mempedulikan jiwa-jiwa yang terhilang. Mereka merasa aman karena sudah memiliki keselamatan itu. Yesus keluar dari zona nyaman untuk memberitakan kabar baik kepada perempuan itu. Yesus tidak takut dengan persepsi-persepsi yang akan datang dari orang-orang Samaria maupun orang-orang Yahudi.

Sebagai orang percaya kadang kala kita enggan untuk keluar memberitakan kabar baik kepada orang-orang yang belum percaya oleh karena perbedaan budaya, ras maupun golongan-golongan yang ada di masyarakat yang pada akhirnya membuat kita tinggal dalam zona nyaman. Yesus menghadapi perbedaan-perbedaan yang menjadi penghalang Injil tersebut tidak di dengar dan meruntuhkan penghalang- 
penghalang itu. Yesus mengetahui apa yang Bapa kehendaki untuk Dia lakukan, begitu pun dengan orang percaya, dengan keluar dari zona nyaman untuk memberitakan kabar baik dengan tidak memandang perbedaan-perbedaan yang menjadi dinding pemisah, itu artinya kita sedang melakukan apa yang dikehendaki oleh Allah.

Penulis melihat model pendekatan Yesus kepada perempuan Samaria ini sungguh sangat unik dan menarik, sebab Ia tidak datang seperti orang Yahudi pada umumnya (bandingkan ayat 9) yang jarang sekali, bahkan enggan bergaul dengan orang Samaria. Tetapi Yesus berbeda, Dia justru lebih dulu mendekati orang Samaria itu, dan inilah yang membuat perempuan itu heran atas sikap Yesus yang sangat luar biasa itu, di mana Yesus mau bergaul dengan orang yang biasanya dibenci oleh orang Yahudi, terlebih lagi mengingat bahwa dia seorang perempuan. Perempuan Samaria itu haus akan kebutuhan jasmani dan Yesus menggunakannya sebagai jembatan untuk memberitakan kasih karunia Allah kepadanya.

\section{Membangun Persahabatan}

Yesus melintasi daerah Samaria dan memulai percakapan dengan seorang perempuan Samaria, karena Ia ingin membangun persahabatan dengannya. Makmur Halim mengatakan bahwa Yesus mengadakan friendshi ${ }^{90}$ dengan orang-orang yang tidak dikenal sebelumnya seperti kepada perempuan Samaria ini. ${ }^{91}$ Persahabatan yang dibangun Yesus dimulai dengan sikap yang merendah yaitu meminta tolong kepada perempuan itu. Tenney berpendapat kalimat "Berilah Aku minum" yaitu permintaan yang Yesus ajukan itu tidak mungkin ditolak oleh perempuan Samaria ini, karena Ia meminta atas dasar kebaikannya. ${ }^{92}$ Pendapat ini menjelaskan bahwa Yesuslah yang memulai membangun atau menjalin persahabatan dengan perempuan itu. Yesus tidak datang seperti seorang yang mengajar atau mendikte apa yang ingin disampaikan, tetapi menempatkan diri-Nya di bawah, sehingga perempuan ini menjadi heran, karena biasanya sorang Yahudi tidak ingin bergaul dengan orang Samaria dan justru sebaliknya membenci mereka (bdg. Ayat 9). ${ }^{93}$ Kristus mengetahui tentang hal itu, oleh karena itu Ia menempatkan diri sebagai orang yang meminta pertolongan, supaya perempuan Samaria itu tidak merasa terancam ataupun tertolak. Suatu

\footnotetext{
${ }^{90}$ Friendship: persahabatan; persobatan; silaturahmi; pertemanan. Indomic EKamus

${ }^{91}$ Makmur Halim, Model-model Penginjilan Yesus Suatu Penerapan Masa Kini, (Malang: Gandum Mas, 2003), 72.

${ }^{92}$ Merril C. Tenney, Injil Iman (Malang: Gandum Mas, 1996), 91.

93 __ Sarapan Pagi, diakses tanggal 29 Mei 2012; tersedia di http://Sarapan pagi.6.forerunner.com/viewtopic.php?.p=1472.
} 
pendekatan yang sangat luar biasa, mengingat kedudukan dan status social-Nya yang jauh lebih tinggi, justru meminta belas kasihan seorang perempuan Samaria yang hina secara sosial. Yesus melakukan hal yang demikian karena ingin menunjukkan sikap yang berbeda yaitu kerendahan hati.

Yesus dengan penuh kerendahan hati melakukan sesuatu yang berbeda, karena tujuan-Nya adalah agar perempuan Samaria ini tahu bahwa kedatangan-Nya dengan maksud baik yaitu memperkenalkan kasih karunia Allah yang telah datang ke dalam dunia dan memberi pengharapan bagi setiap orang berdosa termasuk perempuan Samaria ini. ${ }^{94}$ Jadi, model persahabatan yang dibangun oleh Yesus ketika menginjili perempuan Samaria ini perlu dicontoh. Ketika membangun persahabatan dengan orang yang belum percaya, Injil pun dapat diberitakan dengan baik. Makmur Halim mengatakan, "Di dalam persahabatan ini kita akan menemukan kesempatan-kesempatan untuk memberitakan Injil, sebab melalui persahabatan bisa menemukan adanya kebutuhan khusus dari sahabat atas keterbukaan bersama, ada jalur dalam pembicaraan untuk pemberitaan Injil." ${ }^{95}$ Dari penjelasan Makmur Halim di atas maka penulis mengerti bahwa Yesus terlebih dahulu membangun persahabatan dengan perempuan Samaria itu, karena melalui persahabatan ada sikap saling terbuka, sehingga membuat perempuan itu semakin heran dan penasaran ingin mengetahui lebih banyak lagi tentang diri Yesus.

\section{Membangkitkan Kesadaran Akan Ketidakwajaran Cara Hidupnya}

Tindakan perempuan Samaria yang datang mengambil air ke sumur Yakub pada waktu tengah hari, merupakan hal yang tidak lumrah dan menimbulkan pertanyaan-pertanyaan bagi orang yang belum mengenalnya. Tetapi bisa saja ia menutupinya dengan berbagai alasan untuk membenarkan diri. Dengan menyuruh memanggil suaminya, Yesus sedang membangkitkan kesadaran perempuan itu, bahwa kehidupan yang dimilikinya tidak wajar, karena laki-laki yang hidup bersamanya itu sesungguhnya bukan suaminya. Perkataan Yesus menyentuh hati nuraninya yang terdalam yang menyebabkan dirinya sadar bahwa ia adalah seorang yang berdosa. Makmur Halim berpendapat sebagai berikut: "Pengamatan moral yang tepat dari Yesus membuat perempuan ini menaruh hormatnya bahwa Yesus adalah nabi." 96 Yesus mengungkapkan ketidakwajaran dalam hidup perempuan tersebut

\footnotetext{
${ }^{94}$ Guido Tisera, Firman Telah Menjadi Manusia (Semarang: Kanisius 1992), 43.

${ }^{95}$ Makmur Halim, Model-model Penginjilan Yesus Suatu Penerapan Masa Kini, (Malang: Gandum Mas, 2003), 72

${ }^{96}$ Makmur Halim, Model-model Penginjilan Yesus..., 73.
} 
adalah rencana rahasia-Nya sebagai Allah yang maha mengetahui, sebab syarat bagi seseorang yang ingin mengalami damai sejahtera dari Allah adalah harus meninggalkan kebiasaan moral yang tidak sesuai dengan kehendak-Nya. Jadi perempuan ini harus meninggalkan kebiasaan itu, supaya ia dapat menerima kasih karunia Allah yaitu berupa damai sejahtera dari Yesus.

Jadi, penting untuk membangkitkan kesadaran akan ketidakberesan hidup seseorang yang belum percaya, dengan tujuan supaya orang tersebut bisa menerima kasih karunia Allah. Pada dasarnya orang mau menerima kasih karunia Allah karena ia sadar bahwa dirinya orang yang berdosa dan membutuhkan pertolongan.

\section{Memulihkan Cara Hidup Yang Salah}

Pertemuan Yesus dengan perempuan Samaria bertujuan memulihkan cara hidupnya yang salah. Sesungguhnya perempuan ini tidak suka menjadi orang yang tertolak di masyarakat. Kehadiran Kristus membawa perubahan yang sangat luar biasa di mana perempuan tersebut berubah kearah yang benar. ${ }^{97}$ Awalnya ia seorang yang murung, menderita, kesepian, tertolak, terhina, tetapi pada akhir percakapan dengan Tuhan Yesus ia berubah menjadi orang yang penuh sukacita; bahkan dengan penuh semangat ia kembali ke kota untuk memberitahu semua orang yang mau mendengarnya tentang semua yang telah dikatakan Yesus kepadanya.

Di dalam melaksanakan penginjilan, sangatlah diperlukan suatu pemahaman yang searah dari orang yang menjadi sasaran penginjilan, yaitu pemahaman yang alkitabiah, karena pemahaman yang salah akan berpengaruh pada cara atau praktik hidup seseorang. Oleh sebab itulah perlunya upaya untuk merekonstruksi pemahaman yang keliru tersebut, agar berita yang disampaikan dapat dipahami dengan benar sehingga orang tersebut kemudian dapat menikmati cara hidup yang benar. Dalam percakapan yang terjadi terungkap bahwa perempuan itu meyakini bahwa gunung Gerizim adalah tempat ibadah yang benar kepada Allah, tetapi Yesus berkata bahwa tempat bukan soal agar bisa menyembah Allah dengan benar, tetapi yang terpenting adalah pribadi orang yang beribadah, yaitu menyembah Allah dalam roh dan kebenaran. ${ }^{98}$

\footnotetext{
${ }^{97}$ Bigman Sirait, Penginjil Harus Mengalami Pertobatan, diakses 12 Juni 2012; tersedia di www.reformata.com/0262-pdt-bigman-sirait-penginjil-harus-mengalamipertobatan. 1981), 49 .

${ }^{98}$ F. Haselaars, Injil dan Surat-Surat Yohanes (Yogayakarta: Yayasan Kanisius,
} 


\section{Memberitakan Yesus Adalah Mesias}

Sewaktu bertemu dengan perempuan Samaria, Yesus menggunakan metode pendekatan yang sangat baik, yang mana metode yang digunakan membuat perempuan itu sangat ingin mendengar apa yang hendak dikatakan-Nya.

Pada waktu meluruskan pandangan yang keliru dari perempuan itu, Yesus tidak langsung menanamkan konsep orang Yahudi yang mengatakan bahwa Mesias akan datang sebagai raja, tetapi Yesus perlahan-lahan menyampaikan sesuai dengan konsep dan pemahaman perempuan itu tentang "Mesias" 99 sebagaimana dikatakan perempuan itu kepada-Nya: "Aku tahu, bahwa Mesias akan datang, yang disebut juga Kristus; apabila Ia datang, Ia akan memberitakan segala sesuatu kepada kami" (bdg. ayat 25). Tenney mengatakan dalam bukunya yang berjudul Injil Iman sebagai berikut: "Kata-kata ini sekaligus merupakan pengakuan akan ketidaktahuan dan pengharapan perempuan yang sedang menunggu terang, dan walaupun ternoda ia bergantung kepada janji Allah dari purbakala bahwa Pelepas akan datang dan membuang kegelapan dari matanya." 100

Hal ini menyatakan bahwa pemahaman perempuan itu cukup dalam, sebab penyampaian Kristus tentang keselamatan sangat dimengerti oleh perempuan itu. Yesus tidak memberitakan sesuatu tanpa tujuan, tetapi Ia mempunyai fokus pemberitaan dan tujuan akhir, yaitu untuk memperkenalkan yaitu diri-Nya sendiri, yang adalah jalan keselamatan.

Dalam memberitakan Injil dibutuhkan suatu tujuan jelas. Di mana inti berita yang ingin disampaikan adalah mengenai pribadi Kristus sebagai jalan menuju keselamatan. Sebab Dialah satu-satunya yang dapat menjamin keselamatan setiap orang yang percaya kepadaNya agar memperoleh hidup yang kekal. ${ }^{101}$ Dalam menyampaikan Injil dibutuhkan metode yang baik, tetapi metode yang digunakan pada akhirnya harus menyampaikan isi berita dan tidak meleset dari sasaran yang ingin dicapai.

${ }^{99}$ Mesias dalam konsep orang Samaria yaitu yang mereka nantikan bukan seorang Raja, dan bukan seorang Juru Selamat. Dia akan melayani sebagai nabi yang utama, sesuai dengan Ulangan 18:15-19. Nabi yang mereka nantikan akan memberitakan segala sesuatu kepada mereka. F. Haselaars, Injil dan Surat-Surat Yohanes..., 60.

${ }^{100}$ Merril C. Tenney, Injil Iman ..., 92.

${ }^{101}$ Manford George Gutzke, Plain Talk On John (Grand Rapids: Zondervan Publishing Hous, 1986), 49. 


\section{Model Penginjilan Perempuan Samaria}

Setelah menguraikan model penginjilan Yesus, berikutnya penulis juga akan menguraikan model penginjilan perempuan Samaria di mana model ini dapat digunakan dalam kehidupan orang percaya masa kini.

\section{Mengalami Perjumpaan Dengan Kristus}

Perjumpaan dan pembicaraan dengan Tuhan Yesus telah mengubah hidup perempuan Samaria itu secara radikal. Hidupnya tidak seperti hari-hari sebelumnya. Sesuatu telah terjadi dalam hidupnya sebagai akibat perjumpaan dan pembicaraannya dengan Tuhan Yesus. Semuanya karena inisiatif Tuhan Yesus. Tuhan Yesus yang mencarinya. Tuhan Yesus juga yang membimbingnya dalam percakapan, sampai ia mengenal siapa Yesus dan terbuka pada pembaruan dari Yesus atas hidupnya. ${ }^{102}$

Untuk dapat menjadi seorang penginjil yang memberitakan kabar baik kepada orang-orang yang belum percaya kepada Yesus terlebih dahulu harus mengalami perjumpaan dengan Tuhan Yesus secara pribadi seperti yang dialami oleh perempuan Samaria. Melalui perjumpaan tersebut ia mengalami suatu perubahan hidup yang membawanya mengerti dan mengenal Allah secara pribadi dalam hidupnya. Perjumpaan pribadi dengan Tuhan Yesus, membawa orang percaya kepada pengenalan yang benar tentang Yesus.

D.W. Ellis menjelaskan :

Orang percaya wajib memperkenalkan Kristus kepada orang lain. Tapi merupakan syarat utama, untuk membawa dan memperkenalkan seseorang kepada Kristus, kita harus lebih dahulu mengenal Kristus sebagai Juruselamat kita. Kita harus yakin akan hubungan kita dengan Dia. Kalau kita sudah yakin akan keselamatan kita, hal ini tidak berarti kita boleh hidup semau kita. Melainkan keyakinan kita akan karya Kristus bagi kita secara pribadi, akan memacu orang percaya lebih giat memberitakan Injil Yesus Kristus. ${ }^{103}$

Perjumpaan dengan Kristus secara pribadi adalah hal utama bagi setiap orang percaya. Sebab tanpa perjumpaan dengan Kristus tidak

\footnotetext{
${ }^{102}$ Blessing Family Centre Surabaya, Percakapan Yesus Dengan Perempuan Samaria, diakses 08 Juni 2012; tersedia di http://doauntukanda2.blogspot.com/2010/08/percakapan-yesus-denganperempuan.html.

${ }^{103}$ D.W. Ellis, Metode Penginjilan (Jakarta: Yayasan Komunikasi Bina Kasih/OMF, 2005), 100 .
} 
mungkin seseorang dapat menjadi saksi Kristus yang membawa kebenaran dalam hidupnya. ${ }^{104}$ Penginjil harus mengalami perjumpaan dengan Kristus terlebih dahulu sebelum menjadi saksi bagi Kristus dan menjadi berkat bagi hidup sesama.

\section{Mengalami Pertobatan}

Perjumpaan dengan Yesus membuat wanita Samaria ini tidak dapat menyembunyikan sesuatu dosa pun dari hadapan Tuhan. Ia menyadari bahwa dosa akan menghalanginya untuk menerima air hidup itu. Sebagai orang percaya sangat penting mengalami pemulihan dari Allah sebelum pergi bersaksi memberitakan Injil buat orang lain.

D.W Ellis mengatakan:

Apabila seseorang sadar ia berdosa sesudah melakukan kejahatan, maka kesadaran itu adalah hasil pekerjaan Roh Kudus. Apabila seseorang menginginkan hubungan yang baik dengan Allah, keinginan itu adalah hasil pekerjaan Roh Kudus. Apabila seseorang yang belum percaya, takut memikirkan hukuman Allah yang akan datang, itu adalah hasil pekerjaan Roh Kudus dalam hatinya. ${ }^{105}$

Pengakuan perempuan Samaria akan dosanya adalah pekerjaan Roh Kudus. Setiap orang percaya harus mengizinkan Roh Kudus bekerja, untuk membawa orang percaya tersebut kepada kesadaran akan dosa, yang memerlukan pemulihan dari Tuhan. Orang percaya tidak dapat memberitakan Injil, ketika ia tidak menyadari dosa, mengakui dosa, bertobat dan mengalami pemulihan dari Allah, karena Injil berbicara tentang berita pengampunan dosa.

Pertobatan adalah sebuah urapan, itu adalah karunia dari Allah. Pertobatan adalah sebuah roh yang turun ke atas manusia untuk melembutkan hati mereka dan mengubah pikiran mereka (Za. 12:10). Kalau Allah tidak memberi orang percaya kasih karunia ini dalam kemahakuasaan-Nya, orang percaya tersebut tidak akan mampu hancur hati dan berubah (Rm. 2:4). Pertobatan secara harafiah berarti "mengubah pikiran."

${ }^{104}$ GBI Modernland, Peran Perempuan Dalam Multiplikasi dan Promosi, diakses 08 Juni 2012; tersedia di http:/gbimodernland.org/index.php?option=com content\&eview=article\& \&id=223:peranperempuan-dalam-multiplikasi-dan-promosi\&ecatid=907:warta-sepekan\&Itemid=173. 2005), 55.

${ }^{105}$ D.W. Ellis, Metode Penginjilan (Jakarta: Yayasan Komunikasi Bina Kasih/OMF,

${ }^{106}$ Paul G. Caram, Kekristenan Sejati (Jakarta: Voice of Hope, 2004), 118. 
Sangat penting bagi seorang penginjil mengalami pertobatan. Karena banyak orang menjadi penginjil tetapi pertobatannya diragukan. Orang akan bertanya-tanya tentang perilaku dan gaya hidup yang tidak mencerminkan kehidupan sebagai orang percaya. Orang akan berfikir bahwa ia hanya fasih lidah dan pintar bicara. Ia meminta orang bertobat, tetapi ia sendiri tidak mempunyainya. Menjadi penginjil harus punya visi yang jelas, seperti perempuan Samaria itu. Kristus sudah memanggil dia, Kuasa Roh Kodus itu mengubah dan menggugah hatinya sehingga ia memiliki keberanian yang luar biasa, bukan karena kemampuan dirinya tetapi karena kemurahan dan panggilan Yesus. Pertobatan harus diikuti panggilan yang aktual. Penginjil diukur dari perkataannya. Perempuan itu tidak berkata-kata tentang diri atau kehebatannya. Tetapi dia berbicara tentang apa yang Yesus perbuat atas dirinya. Kalau sekarang, banyak orang Kristen berbicara tentang dirinya yang hebat, sampai berita tentang Kristus pun tenggelam. Penginjil bukan hanya diukur dari perkataan, tetapi juga perbuatan. ${ }^{107}$

Pertobatan berarti memandang keselamatan dari perspektif kita. Ini merupakan suatu proses dari keseluruhan karya anugerah Allah, mulai dari pencerahan, pengertian dan pencarian yang pertama kali, dan berakhir dengan Kristus dalam kelahiran baru. Bagi beberapa orang, proses ini memakan waktu bertahun-tahun; bagi orang-orang lain, mungkin hanya satu jam. Kita merespons sesuai dengan waktu Allah dalam kekekalan..$^{108}$

\section{Hidup Dalam Penyembahan}

Allah harus menjadi yang paling pertama dan pusat dalam seluruh kegiatan hidup orang percaya. Perintah terbesar dalam Perjanjian Lama dan Perjanjian Baru ialah kasihilah Tuhan Allahmu dengan segenap hati, dengan segenap jiwa, dengan segenap kekuatan dan dengan segenap pikiran. Perintah ini mula-mula dilakukan orang Israel tetapi makin lama, makin menjadi satu kebiasaan sehingga waktu Yesus datang, Ia

\footnotetext{
${ }^{107}$ Bigman Sirait, Penginjil Harus Mengalami Pertobatan, diakses 6 Juni 2012; tersedia di http://www.reformata.com/0262-pendeta-bigman-sirait-penginjil-harus-mengalamipertobatan.html.

${ }^{108}$ Istilah Pertobatan seringkali didefinisikan sebagai respons awal dari iman dan pertobatan seseorang. Terkadang kamu Puritan menggunakan sejumlah istilah untuk menggambarkan urutan dari berbagai aspek pekerjaan Roh. Seorang pendosa mulai tergugah (kepekaan baru terhadap Allah) lalu mencari (mencari jawaban) lalu menyesal (merasa berdosa) lalu bertobat (iman dan pertobatan) oleh Will Metzger, Tell The Truth (Surabaya: Momentum, 2005), 177.
} 
mengubah kembali pikiran dunia ini dan membawa mereka kepada pusat penyembahan yang sebenarnya yaitu diri-Nya sendiri. ${ }^{109}$

Warren dan Ruth Myers menjelaskan:

Tuhan Yesus menghendaki kita sadar bahwa penyembahan merupakan respons atau tanggapan roh kita. Penyembahan tidak hanya melibatkan gerakan tubuh yang dapat dilihat. Penyembahan harus keluar dari roh kita, bagian terdalam dari manusia. Penyembahan tidak bergantung pada hal-hal luar, seperti tempat tertentu, keadaan sekeliling yang indah, tata cara yang sudah lazim, musim khusus, atau gerakan tubuh. ${ }^{110}$

Pertobatan perempuan Samaria membawanya kepada hidup yang menyembah. Penyembahan menghasilkan motivasi untuk menginjil. Penyembahan menghasilkan suatu kerinduan untuk menceritakan pada orang lain tentang Yesus Kristus.

Will Metzger menjelaskan:

Perempuan Samaria itu telah tiba pada suatu titik di mana apa yang dipikirkan orang lain mengenai dirinya tidak penting. Perubahan perspektif ini bukan disebabkan karena perempuan itu dikucilkan; namun ini timbul karena perjumpaan individual dengan Allah yang hidup, suatu perjumpaan yang membawa kepada kasih dan pemujaan kepada penyembahan. Penyembahan yang kuat akan mendorong orang percaya untuk bersaksi. Ini mengalihkan fokus perhatian kita dari pendapat diri sendiri dan pendapat orang lain kepada kebesaran Allah dan kasih-Nya yang ajaib. Sepanjang masa, orang-orang yang telah menaklukkan kepentingan dirinya sendiri dan terlibat dalam pekerjaan Allah selalu berimbas pada orang lain dalam penginjilan. Pengalaman penyembahan memobilisasi kita untuk bersaksi. ${ }^{111}$

\section{Kesaksian}

Seorang pendosa, betapapun buruknya, ia tetap bisa menjadi saluran berkat keselamatan bagi banyak orang, perempuan Samaria ini sudah membuktikannya. Dengan air hidup, ia telah dipuaskan, dan kembali pula ia memancarkan kasih karunia itu kepada orang lain

12.

${ }^{109}$ G. Bennett, Penyembahan (Makassar: Sekolah Tinggi Theologia Jaffray, 1986), Babtis, 2004), 40

${ }^{110}$ Warren \& Ruth Myers, Pujian dan Penyembahan (Bandung: Lembaga Literatur

${ }^{111}$ Will Metzger, Tell The Truth (Surabaya: Momentum, 2005), 177. 
disekitarnya. Dari kisah ini, ia seorang perempuan yang menerima 'cap buruk', seorang perempuan yang dipandang lebih rendah dari masyarakat sekitarnya, namun dia telah dipulihkan oleh Yesus. Hidupnya berubah menjadi pengabar Injil yang dahsyat, kesederhanaan imannya mampu menggiring orang-orang lain untuk datang kepada Yesus. Pembaharuan yang diperolehnya melalui penginjilan yang disampaikan oleh Yesus itu, ia tidak lagi dibelenggu kesalahan dan dosanya pada masa lalu. Ia telah menjadi manusia baru, menjadi penyembah rohani yang tidak dibatasi lokasi, gender dan ras, ia mengabarkan pula kepada orang-orang lain untuk menjadi penyembah rohani yang sama dengan dirinya dan datang kepada Yesus untuk diselamatkan. ${ }^{112}$

Ketika Yesus datang ke Samaria, Dia hanya menemui satu orang yaitu perempuan yang hidup dalam perzinahan. Pertemuan ini membuahkan pertobatan. Setelah membukakan semua dosanya, Yesus memulihkan hidup perempuan ini. Perempuan tersebut kemudian bersaksi kepada orang-orang di kotanya. Ia mengajak mereka melihat Yesus. Ajakan ini sangat efektif. Banyak orang datang kepada Yesus, bahkan meminta-Nya tinggal dua hari bersama mereka. Padahal orang Samaria biasanya antipati terhadap orang Yahudi seperti Yesus. Orangorang itu akhirnya percaya kepada Yesus. Bukan lagi karena ajakan perempuan itu, melainkan karena mereka kini telah mengenal Yesus secara pribadi.

\section{Karya Roh Kudus}

Penginjilan bukanlah pekerjaan manusia (posisi manusia dalam penginjilan hanya sebagai alat), melainkan pekerjaan Allah, maka dari itu dalam melaksanakan penginjilan harus bersandar sepenuhnya kepada Roh Kudus. Roh Kuduslah yang menuntun penginjil dalam melaksanakan tugasnya. Ia pula yang menuntun penginjil ke tempat, daerah, atau orang yang respon terhadap pemberitaan Injil.

Roh Kuduslah yang memberi kemampuan bagi penginjil untuk menjelaskan kebenaran Firman Tuhan dengan penuh kuasa, karena pemberitaan Injil tidak hanya diplomatisnya kata-kata, tetapi pemberitaan harus memiliki kuasa sehingga pada gilirannya menjadikan satu perubahan yang besar dalam hati orang yang menerima pemberitaan Injil. Roh Kudus pula yang bekerja di dalam hati setiap orang yang diinjili. Dialah yang membuat orang yang diinjili mengerti kebenaran Firman Tuhan, Dialah yang menyadarkan setiap orang untuk bertobat dari dosanya (Yohanes 14:15-31; 16:4b-15).

\footnotetext{
${ }^{112}$ Bagus Pramono, Yesus Dan Perempuan Samaria, diakses 06 Juni 2012; tersedia di http://www.sarapanpagi.org/yesus-dan-perempuan-samaria-vt465.html.
} 


\section{PENUTUP}

\section{Kesimpulan}

Pertama, penginjilan adalah tugas utama bagi setiap gereja dan orang percaya secara pribadi yang telah menerima keselamatan dari Allah. Kedua, penginjilan adalah wujud kasih orang percaya kepada Allah dan kepada sesama manusia. Ketiga, penginjilan adalah pekerjaan yang mulia, sebab membawa setiap manusia mengenali akan dosanya lalu bertobat menerima Yesus sebagai juruselamat, dan percaya dengan sungguh bahwa di dalam Yesus ada keselamatan, pengharapan dan kepastian hidup yang kekal. Keempat, Penginjilan merupakan pelayanan yang memiliki kekuatan Kuasa Allah, dan hal ini hanya dapat dilakukan oleh Roh Kudus (Lukas 24:49). Kelima, Sebelum memulai pemberitaan Injil terlebih dahulu haruslah menerima kuasa Roh Kudus. Sebab hanya melalui kuasa Roh Kudus, akan memampukan setiap orang percaya bergerak keluar melakukan pemberitaan Injil.

\section{Saran-Saran}

Berdasarkan kesimpulan yang telah penulis uraikan di atas, maka pada bagian ini penulis akan memberikan saran-saran yaitu: Pertama, diharapkan agar setiap pemimpin Kristen terutama gembala jemaat harus mempunyai paradigma yang benar terhadap penginjilan dan memiliki jiwa penginjilan agar dapat pendorong jemaat untuk menginjil, sebab manakala gembala tidak memiliki pengertian yang jelas, agak sulit untuk gembala mendorong jemaat untuk terbeban terhadap tugas penginjilan. Kedua, jemaat harus didorong untuk memiliki beban terhadap penginjilan dan mulai dengan kegiatan-kegiatan doa. Ketiga, gereja harus memberikan seminar dan pengajaran tentang pentingnya melakukan penginjilan kepada orang-orang yang belum percaya. Keempat, setiap orang percaya menyadari pentingnya hidup dalam pertobatan dan penyembahan yang benar kepada Allah. Kelima, setiap orang percaya pasti memiliki karunia yang dapat dikembangkan sesuai dengan fungsinya untuk kegiatan pelayanan Tuhan. Untuk itu hendaknya orang percaya menyadari dan bersedia memberikan diri untuk diperlengkapi oleh gereja agar pergi menjalankan pelayanan penginjilan. Keenam, membiasakan diri untuk terlibat dalam persekutuan doa yang diadakan di dalam gereja demi kelancaran penginjilan. 


\section{KEPUSTAKAAN}

Alkitab

Alkitab, Jakarta: Lembaga Alkitab Indonesia, 2002.

Alkitab Penuntun Hidup Berkelimpahan. Malang: Gandum Mas, 1994.

Kamus

Browning, W.R.F, Kamus Alkitab. Jakarta: PT. BPK. Gunung Mulia, 2007.

Ensiklopedi Alkitab Masa Kini. Jakarta: Yayasan Komunikasi Bina Kasih/OMF, 1995.

Sutanto, Hasan. Perjanjian Baru Interlinear Yunani-Indonesia dan Konkoordansi Perjanjian Baru (PBIK) Jilid 1, 2. Jakarta: LAI, 2003.

Buku-buku

Abineno, J. L. Ch., Yesus Sang Mesias dan Sang Anak. Jakarta: BPK Gunung Mulia, 1999

Barclay, William. Pemahaman Alkitab Setiap Hari. Jakarta Pusat: BPK Gunung Mulia, 1983.

Bonnke, Reinhard. Penginjilan Dengan Api. Jakarta: Yayasan Pekabaran Injil Immanuel, 1978.

Borthwick, Paul. Pemberitaan Injil Tugas Siapa?. Bandung: Yayasan Kalam Hidup, 1987.

Brandt L, Robert. Memenangkan Jiwa. Malang: Gandum Mas, 1983.

Brill, J. Wesley. Tafsiran Injil Yohanes. Bandung: Kalam Hidup, 1976

Crosby, Michael H. Apakah Engkau Mengasihi Aku? Jakarta: BPK Gunung Mulia, 2009

Darmawijaya, St. Pesan Injil Yohanes. Yogyakarta: Kanisius, 1986.

Ginny, Lum, Ada. Misi Allah Bagi Dunia.Jakarta: Perkantas, 1992.

Graham, Billy. Beritakan Injil Standar Alkitabiah Bagi Penginjil. Yogyakarta: Yayasan Andi, 1992.

Guthrie, Donald, Pengantar Perjanjian Baru, Vol. 1 (Surabaya: Momentum, 2010.

Hagelberg, Dave. Tafsiran Injil Yohanes. Yogyakarta: Yayasan Andi, 1999. Tafsiran Injil Yohanes Pasal 1-5 Dari Bahasa Yunani Yogyakarta: Yayasan Andi, 1990.

Halley, Henry H., Penuntun Ke Dalam Perjanjian Baru (Surabaya: Yakin, 1965), 148.

Harrison, Everett F., Injil Yohanes Penjelasan Alkitab Untuk Kaum Awam. Jakarta: BPK Gunung Mulia, 1985

Henry, Matthew. Injil Yohanes 1-11. Surabaya: Momentum, 2010

Jensen, Irving. Yohanes. Bandung: Kalam Hidup, 1970. 
Johanes, Verkuyl R.W \& John Stott, Misi Menurut Perspektif Alkitab. Jakarta: Yayasan Komunikasi Bina Kasih, 2007.

Kuiper, de. Misiologia. Jakarta: BPK Gunung Mulia, 1988.

Kysar, Robert. Injil Yohanes Sebagai Cerita. Jakarta: BPK Gunung Mulia, 1995.

Leon, Xavier. Ensiklopedi Perjanjian Baru. Yogyakarta: Kanisius, 1990

Merrlil, Tenney C. Injil Iman. Malang: Gandum Mas, 1996.

Packer, J.I. Evangelism And The Sovereignty Of God. Surabaya: Momentum, 2009.

Packer, Tenney \& William. Dunia Perjanjian Baru. Malang: Gandum Mas, 1995.

Stott, R.W, John. Fundamentalisme dan Penginjilan. Bandung: Kalam Hidup, 1975.

Sutanto, Hasan. Perjanjian Baru Interlinear Yunani-Indonesia dan Konkordansi Perjanjian Baru (PBIK). Jakarta: LAI, 2003.

Tenney, Merrill. Yohanes: Injil Iman. Malang: Gandum Mas, 1996. . Survei Perjanjian Baru Malang: Gandum Mas, 1993

Tomatala, Y. Y. Penginjilan Masa Kini. Malang: Gandum Mas, 1997.

Tong, Stephen. Teologi Penginjilan. Jakarta: Lembaga Reformed Injili Indonesia, 1988.

W, Ellis. D. Metode Penginjilan. Jakarta: Yayasan Komunikasi Bina Kasih, 1999.

Weslley, Brill. Tafsiran Injil Yohanes. Bandung: Kalam Hidup, 1976. X nm.

Wismoady, Wahono S. Di Sini Kutemukan. Jakarta: BPK Gunung Mulia, 1987.

Tafsiran Alkitab Masa Kini 3. Jakarta: Yayasan Komunikasi Bina Kasih, 1983. "Strategi Misi Model Kontekstualisasi," Buletin Mitra. OktoberDesember 2007.

Internet

Blessing Family Centre Surabaya, Percakapan Yesus Dengan Perempuan Samaria, diakses 08 Juni 2012; tersedia di http://doauntukanda2.blogspot.com/2010/08/percakapan-yesusdengan-perempuan.html

GBI Modernland, Peran Perempuan Dalam Multiplikasi dan Promosi, diakses 08 Juni 2012; tersedia di http://gbimodernland.org/index.php?option=com_content\&\&view= article\&id=223:peran-perempuan-dalam-multiplikasi-danpromosi\&catid=907:warta-sepekan\&Itemid=173. 